\title{
Distributional Effects of Crises: The Role of Financial Transfers*
}

\author{
by \\ Marina Halac Sergio L. Schmukler
}

This draft: October, 2003

\begin{abstract}
Financial crises affect income distribution via different channels. In this paper, we argue that financial transfers are an important channel, which has been overlooked by the literature. We study the role of financial transfers by analyzing some of the most severe Latin American crises during the last decades (Chile 1981-1983, Mexico 1994-1995, Ecuador 1998-2000, Argentina 2001-2002, and Uruguay 2002). First, we investigate transfers to the financial sector, which are those from non-participants to participants of the financial sector. Second, we explore who receives these financial transfers by identifying the winners and losers within the financial sector. Our analysis suggests that financial transfers during crises are large and expected to increase income inequality.
\end{abstract}

Keywords: financial crises, distributional effects, financial transfers, inequality, income distribution

JEL classification: E44, E60, F41, G20, I32

\footnotetext{
* We thank François Bourguignon, Chico Ferreira, Roberto García-Saltos, Eduardo Levy Yeyati, Guillermo Perry, Luis Servén, Andrés Velasco, and Mike Walton for very useful comments. This paper is a product of the background work for the World Bank Latin America and the Caribbean Flagship Report 2003 "Inequality and the State in Latin America." We also thank José Gavilanes from AGD in Ecuador, María Gutierrez from the Superintendency of Banks of Ecuador, and Jorge Polgar from the Central Bank of Uruguay for help with the data. The views expressed in this paper are those of the authors and do not necessarily represent those of the World Bank. E-mail addresses: mhalac@worldbank.org and sschmukler@worldbank.org.
} 


\section{Introduction}

The financial crises of the last decades have attracted much attention among economic researchers and policymakers. Different papers investigate the causes, dynamics, and effects of banking and currency crises. ${ }^{1}$ With respect to the consequences, the literature focuses on the aggregate impact of crises on the overall economy and on the financial system. Several papers measure the cost of crises by studying their depth and duration, defined as the cumulative output loss and recovery time, concluding that financial crises have been very costly for developed and emerging economies. For example, during the period 1973-1997, there were more than 44 crises in developed countries and 95 in emerging markets, with average output losses of 6.25 and 9.21 percent of the gross domestic product (GDP) respectively. (See Bordo et al. 2001 and Eichengreen and Bordo 2002.)

Crises do not hit all groups of people equally, despite the overall negative impact on output. Several studies analyze how crises affect disproportionately different ranges of the income distribution. The literature identifies four main channels through which crises affect households and, in particular, the poor (see for example Baldacci, de Melo, and Inchauste 2002, Ferreira, Prennushi, and Ravallion 1999, and Manuelyan and Walton 1998). First, financial crises generally lead to slowdowns in economic activity and, consequently, to a reduction in labor demand. Adverse income and employment shocks hurt the poor most because they do not have the means to protect themselves. They lack assets to hedge against these shocks and often have no direct access to credit markets to

\footnotetext{
${ }^{1}$ See, among many others, Burnside, Eichenbaum, and Rebelo (2001), Calvo and Reinhart (2000), Chang and Velasco (2001), Eichengreen and Rose (2000), Esquivel and Larraín (1998), Frankel and Rose (1996), Goldfajn and Valdés (1997 and 1998), Kaminsky (1998), Kaminsky and Reinhart (1999), Milesi-Ferretti and Razin (2000), and Sachs, Tornell, and Velasco (1996).
} 
smooth their impact. Furthermore, the "labor hoarding" hypothesis highlighted by Agénor (2002) indicates that unskilled workers (typically poor people) are often the first to lose their jobs as firms "hoard" their trained labor force., ${ }^{2,3}$ Second, financial crises affect both the wealth and the income of the poor through high inflation, which tends to accompany these shocks and their resolution. As the poor normally hold a greater proportion of their wealth in cash than the non-poor, they tend to be more affected by the increased rate of inflation (which is a tax on money holding). ${ }^{4}$ Also, as nominal wages are not perfectly linked to the price index, inflation leads to a decline in real wages. This affects the poor more than the rich because poor people do not have capital rents; moreover, labor earnings constitute a much larger share of their total income. Third, crises may cause changes in relative prices that hurt the poor by accentuating the fall in real wages. The currency depreciation (that is usually associated with crises) may affect the price of imported food, increasing domestic food prices and thus hurting poor households that are net consumers of food (Sahn, Dorosh, and Younger 1997). Fourth, the public spending cutback that is conventionally implemented in response to financial crises severely impacts poor families. Public expenditure cuts, beyond causing declines in labor demand, affect cash transfers to households and the provision of social services. These cuts tend to hurt those who rely on public services, mostly the poor.

The empirical literature that studies the impact of crises on poverty and inequality indicators obtains mixed findings, depending on the country and episode. The common

\footnotetext{
${ }^{2}$ The incentive to hoard is mainly explained by the existence of high turnover costs in the use of skilled labor.

${ }^{3}$ In addition, due to the lack of education and skills, the poor tend to be less mobile and are, therefore, often unable to switch jobs towards available employment opportunities.

${ }^{4}$ The negative implications of inflation for the poor have been shown by, for example, Cardoso (1992) and Easterly and Fischer (2001).
} 
conclusion from this literature is that the poor are more affected than the rich. Lustig (2000) shows that out of 20 crises in Latin America, all were followed by an increase in the poverty headcount ratio, and 15 of them by a rise in the Gini coefficient. Regarding the social costs of the East Asian financial crises of 1997-1998, the evidence also indicates large impacts on poverty. In Indonesia the incidence of poverty rose from 11 to 18 percent in 1996-1999, and in Korea the urban poverty headcount index rose from 8.5 to 18 percent in 1997-1998. ${ }^{5}$ Lopez-Acevedo and Salinas (2000) and Cunningham and Maloney (2000), among others, analyze the Mexican crisis (1994-1995) in detail. In this case, though the incidence of poverty increased between 1994 and 1996, the ten percent richest also experienced losses and, accordingly, inequality went down. ${ }^{6}$ Lokshin and Ravallion (2000) study the welfare impact of the 1998 Russian crisis, finding that the expenditure-poverty rate rose by almost 50 percent from 1996 to 1998 . Finally, there are a few studies across regions documenting the distributional effects of crises. Baldacci, de Melo, and Inchauste (2002) analyze the impact of 65 crisis episodes and show that a fall in GDP per capita in the wake of financial crises is associated with an increase in the incidence of poverty and deterioration in the income distribution. From a different perspective, Diwan (2001 and 2002) investigate how crises affect the distribution of income between labor and capital using a sample of 135 countries. Diwan finds that there is a tendency for the labor share to fall sharply during financial crises, recovering only partially during subsequent years.

\footnotetext{
${ }^{5}$ See Bourguignon, Robilliard, and Robinson (2001) and Friedman and Levinsohn (2002) for detailed studies of the distributional impact of Indonesia's financial crisis.

${ }^{6}$ According to Lopez-Acevedo and Salinas (2000), the top decile protected their income flow with financial and other capital assets during the crisis, but the increase in their financial income did not compensate the drastic fall in their labor earnings. The top decile was concentrated in non-tradable sectors such as financial services, which were the hardest hit from the recession.
} 
In this paper, we argue that financial transfers are an important channel through which crises affect income distribution. To our knowledge, there are no research studies on this channel. We analyze different mechanisms through which financial transfers take place. We first investigate transfers to the financial sector, which are transfers from nonparticipants to participants of the financial sector, including creditors, debtors, and financial institutions. ${ }^{7}$ We then further explore who receives these financial transfers by identifying the winners and losers within the financial sector. For this, we consider asymmetric effects on different participants of the financial sector, such as small and large depositors, domestic and foreign investors, less and more informed individuals, small and large borrowers, and related and non-related companies. ${ }^{8}$ As this is a very difficult topic to study, especially because financial transfers are hard to measure and the available data are very limited, in this paper we take case study approach. The aim of the paper is not to provide formal cross-country or time series econometric estimations of the gains and losses, but instead to illustrate and quantify through different cases the kinds of financial redistributions that occur as a consequence of crises. To do so, we analyze data from the crises of Chile (1981-1983), Mexico (1994-1995), Ecuador (1998-2000), Argentina (2001-2002), and Uruguay (2002), which have been among the most severe crises in Latin America during the last decades. The added value of this paper is that it is the first attempt to tackle this issue and provides new data that are not easy to gather, which may explain why there are no studies on this topic.

\footnotetext{
${ }^{7}$ By financial sector we refer to the banking sector. Though crises may generate important transfers among holders of bonds and equity, we do not cover those redistributions in this paper.

${ }^{8}$ Information asymmetries between foreign and domestic investors have already been covered by the literature but focusing on capital markets (see for example Brennan and Cao 1997, Frankel and Schmukler 2000, Froot et al. 2001, and Kim and Wei 2002).
} 
We find evidence of important wealth redistributions generated through financial transfers during crises. First, we show that the fiscal cost of crisis resolution generally implies transfers from non-participants to participants of the financial sector. Second, differential impacts on participants of the financial sector suggest that only a fraction of them receive these transfers. The Argentine, Ecuadorian, and Uruguayan crises show that large and foreign depositors (or investors with access to foreign-based accounts) obtain compensations or even capital gains, while small depositors suffer capital losses. In addition, the crises of Chile, Ecuador, and Mexico show that large borrowers with close ties with banks are those who result particularly benefited from the crises and their resolution. Finally, given the income level of the different social groups involved in the transfers, our analysis suggests that financial transfers go from poorer to richer households and, thus, may negatively affect the distribution of income. Though we must be cautious in driving general conclusions from country cases, this paper reveals the importance of this new channel of impact.

The rest of the paper is organized as follows. In Section 2, we study financial transfers from individuals outside to those inside the financial sector. In Section 3, we further explore who receives the transfers within the financial sector. In Section 4, we investigate the impact of financial transfers on income inequality. In Section 5, we discuss the policy implications and conclude.

\section{Transfers to the financial sector}

Crises generally produce differential impacts on participants and non-participants

of the financial system. Contrary to what we could expect, consequences for individuals 
outside the financial system may be even worse than for participants of the financial system, even though the crisis is financial. To illustrate these effects, we focus on the resolution of financial crises, mainly studied in the banking crises literature, including papers such as Dziobec and Pazarbasioglu (1997), Hoggarth, Reis, and Saporta (2001), and Honohan and Klingebiel (2003).

Crises always imply costs to the economy. An important cost is the fiscal cost of the resolution, which is the estimated net present value of the budget cost of the crisis (as a percentage of GDP). Figure 1 shows that the fiscal costs of banking crises have been large, especially in emerging markets. For a sample of 40 banking crises, governments have spent an average of 6.2 percent of GDP in developed countries and 14.7 percent of GDP in emerging markets in the resolution. Several authors have estimated the fiscal cost of some of the crises that we study in this paper. For instance, the approximate resolution cost is around 33-42 percent of GDP for the Chilean crisis (Caprio et al. 2003 and Dziobec and Pazarbasioglu 1997), 20-24 percent of GDP for the Mexican crisis (Caprio et al. 2003 and own estimations), and 10-25 percent of GDP for the Ecuadorian crisis (Caprio et al. 2003 and Standard and Poor's 2000).

Who pays these fiscal costs and who receives the benefits? Fiscal costs comprise both fiscal and quasi-fiscal outlays for financial system restructuring, including the costs of bank recapitalizations, bailouts for depositors, and debt relief schemes for borrowers. In other words, fiscal costs are incurred to help the financial system, to alleviate the potential losses of depositors, borrowers, and financial institutions. The government may finance these costs through a combination of a rise in (present or future) taxes, a fall in spending, and an increase in the inflation tax. In this sense, fiscal costs constitute a 
transfer from individuals outside the financial sector to those inside the financial sector. ${ }^{9}$

Below, we illustrate different mechanisms that contribute to this type of transfer with data from the crises of Chile, Mexico, Ecuador, Argentina, and Uruguay.

\subsection{Transfers to depositors}

Two instruments that are generally used by authorities to help depositors are liquidity support and ex-post deposit insurance. These tools are typically implemented when a crisis is unfolding to restore public confidence and avoid a generalized deposit run that can lead to the collapse of the banking system. Liquidity lines and deposit guarantees involve large fiscal outlays, which are amplified by the moral hazard that these tools themselves generate.

Liquidity support includes loans, rediscounts, repos, and other instruments used by the central bank to assist financial institutions facing liquidity problems. These liquidity lines to banks often represent a fiscal cost as they are not fully repaid by the financial institutions. This seems to be the case in many of the Latin American crises that we study. A frequent reason for this is that assisted banks are finally closed or taken over by the government or public organizations. In Ecuador, for example, central bank liquidity support totaling 2.3 billion U.S. dollars between August 1998 and December 1999 was directed to banks that are currently controlled by the Deposit Guarantee Agency (AGD), which was created by the government to insure deposits and resolve

\footnotetext{
${ }^{9}$ Alternatively, we could say that fiscal costs constitute a transfer from the whole population to individuals inside the financial sector, as they are actually paid by all taxpayers. However, as resolution costs are directed towards assisting the financial sector, the (net) burden ultimately falls on those taxpayers that do not participate in the financial sector. In this sense, resolution costs imply a transfer from individuals outside the financial sector to those inside the financial sector, or from the "unbanked population" to the "banked population."
} 
bank failures, or by the government itself. Similarly, in Uruguay, emergency liquidity lines from the central bank, amounting 2.1 billion dollars between January 2002 and August 2002, were mainly directed to three banks severely hit by the deposit outflow, which were then taken over and merged into a new commercial bank (Nuevo Banco Comercial) owned by the government. ${ }^{10}$ In Argentina, the liquidity support provided to financial institutions, which represented more than 8.3 billion dollars by August 2002, is also likely to be not totally repaid by banks but exchanged for government bonds at book value. (Note that the market price of these bonds is low, reflecting the sovereign default.) Only the case of Mexico appears to be different; liquidity support of around 46.4 billion dollars was repaid to the central bank in full by September 1995 (De Luna-Martinez 2000). However, even when loans were repaid, there can still be a fiscal cost of this liquidity assistance if subsidized interest rates are granted to the banks.

Explicit deposit guarantees not established ex-ante but issued as the crisis approaches, as well as implicit protection for depositors, also add greatly to the total fiscal cost of crises. ${ }^{11}$ In Chile in the 1980s, although only a limited explicit guarantee existed for small deposits, most deposits had a de facto 100 percent guarantee. ${ }^{12}$ Moreover, after the banking crisis started in 1981, the Chilean authorities offered in 1983 an explicit deposit guarantee to all depositors to restore confidence, while the effects of the programs implemented to rehabilitate the financial system were taking place. In Mexico, the Credit Institutions Law of 1990 had established Fobaproa (Fondo Bancario

\footnotetext{
${ }^{10}$ The Uruguayan central bank did not, however, provide liquidity assistance to Banco de Galicia Uruguay (BGU), which was the first bank hit by the deposit run (mainly from Argentine depositors) and lost 194 million dollars during January 2002. BGU was a subsidiary of the Argentine bank Banco de Galicia y Buenos Aires S.A. and the second largest private bank in Uruguay. Most of its clients were Argentine individuals and companies.

${ }^{11}$ Ex-ante insurance that is privately funded, on the contrary, would not represent a fiscal cost.

${ }^{12}$ The perception that the government would rescue depositors in the event of a crisis had been reinforced by the bailout of depositors of Banco Osorno, which had collapsed in 1977.
} 
de Proteccion del Ahorro), a trust administered by the central bank, created for preventive support to commercial banks and to protect savings. Though the law did not obligate Fobaproa to explicitly insure any obligations of commercial banks, by the time of the 1994-1995 Mexican crisis Fobaproa implicitly protected 100 percent of deposits. In Ecuador, as the currency and banking system breakdown became imminent in 1998, the government introduced deposit guarantees. The emergency legislation of November 1998 created AGD, providing an explicit guarantee for the international trade-related liabilities and practically all the deposits of banks taken over by AGD for resolution (banks placed under so-called saneamiento). ${ }^{13}$

As a consequence of these ex-post and de facto guarantees, governments incur substantial costs to pay depositors of bankrupt banks. In Chile, the net total cost of covering depositors of the 16 banks liquidated between 1982 and 1986 amounted to near ten percent of the 1983 GDP (Sanhueza 2001). In the cases of Mexico and Ecuador, the cost of bailing out depositors will ultimately depend on the fraction of assets to be recovered by Fobaproa and AGD respectively. However, given the low recovery rates of the restructured debt, it is quite evident that the cost of insuring depositors will be large. In Mexico, for example, Fobaproa had sold only 0.5 percent of the acquired assets by early 1999 (four years after it had been established). ${ }^{14}$ In Ecuador, AGD has paid 850 million dollars to depositors and still has to return deposits for 757 million dollars (in addition to near 1.4 billion dollars that AGD has spent in banks capitalization and

\footnotetext{
${ }^{13}$ Argentina had (ex-ante) a partial deposit insurance scheme that was supposed to cover deposits up to 30,000 pesos or dollars depending on their maturity (though insurance funds were depleted once the crisis and deposit withdrawals started). Uruguay did not have deposit insurance. See Martinez Peria and Schmukler (2001) for more details on the deposit insurance systems.

${ }^{14}$ Klingebiel (2000).
} 
expenses), while recovered assets only amounted to 43 million dollars by May 2003 (see AGD 2003).

\subsection{Transfers to borrowers}

Regarding financial transfers to debtors, the examples above already suggest that a number of borrowers are bailed out in the resolution of crises (even if the programs implemented are not aimed at doing so, but at bailing out creditors). When bank loans are transferred to the central bank or an asset management company, borrowers might find it easier to default their debts. The transfer to debtors tends to be notably large because borrowers often take advantage of the government bailout and stop paying their debts, regardless of their capacity to pay.

The evidence from Ecuador on this type of transfer to borrowers is overwhelming. The top panel of Figure 2 shows that the percentage of past-due loans in the portfolio of banks taken over by the government or AGD has been increasing steadily since December 1998, while the share of past-due loans in other private banks started to decrease already in 2000. The bottom panel of Figure 2 depicts the change in the percentage of past-due loans of banks relative to the takeover date. Being the date in which the bank becomes state-owned or controlled by AGD, the figure shows that the portion of non-performing loans increases after banks are taken over. The data suggest that borrowers abuse of the situation and quit paying their debts, expecting the government to bear the costs and anticipating no serious consequences for their actions.

Another costly measure frequently implemented in the resolution of crises to aid borrowers is debt relief programs. For example, the Chilean central bank established in 
1983 and 1984 schemes to enable banks to reschedule a portion of their firm, mortgage, and consumer loans, benefiting debtors with longer maturities and lower subsidized interest rates. In Mexico, seven programs were launched to help debtors in 1995-1998. The last program (Punto Final), announced in 1998, gave subsidies to debtors with mortgage, small businesses and agricultural loans.

Other mechanisms used to help debtors in the aftermath of crises are aimed at alleviating the negative effects of devaluations. In Chile, for example, to reduce the impact that the June 1982 devaluation of the peso had on foreign currency borrowers, the central bank established a preferential exchange rate for foreign currency denominated debt (the central bank sold dollars to debtors at a subsidized exchange rate). This program was the most expensive of all the resolution tools used by the Chilean central bank. In Argentina, as the devaluation of the peso announced in January 2002 would mean bankruptcy for many debtors (70 percent of the banking system's loans were denominated in dollars), the authorities decreed the conversion of dollar debts to peso debts at one dollar equal to one peso. Considering that total loans denominated in dollars reached approximately 46 billion dollars by January 2002 and that the daily average exchange rate during 2002 was 3.21 pesos per dollar, foreign currency borrowers received a transfer of nearly 32 billion dollars.

\subsection{Transfers to financial institutions}

Financial institutions may also receive transfers during the resolution of crises. For example, a policy measure that is frequently implemented during the resolution and tends to significantly benefit banks is loan-purchase programs. The central bank or an 
asset management company (set up by the government) often buys risky loans from financial institutions to recapitalize them. Banks avoid large potential losses by transferring their non-performing debt to the government. Though the low recovery rates of the restructured debt may be due in part to the opportunistic behavior of borrowers as shown above, they also (and perhaps mostly) reflect the poor quality of the portfolio acquired by the central bank or asset management company. In other words, the loans transferred by banks tend to be "non-recoverable" when the authorities assume them. In this sense, the cost arising from loans that are not recovered would constitute a (sometimes unintended) transfer to financial institutions.

This kind of transfer to financial institutions can imply large fiscal costs. In Chile, for example, where the central bank bought high risk portfolio of banks with a repurchase obligation through future profits, the fiscal cost of this program reached around 6.7 percent of the 1983 GDP (Sanhueza 2003). This cost was due to loans that were never recovered and also to the advantageous interest rate offered by the central bank for the financing of bad loans. The central bank transferred resources worth 8.9 percent of GDP and ended up recovering 2.2 percent of GDP.

The bailout to banks in the resolution of crises is an issue of much debate. On the one hand, one could argue that authorities generally assist banks with the objective of helping depositors and debtors. Liquidity support and capitalizations, for example, are aimed not at benefiting bank shareholders but at preventing a collapse of the financial system that could make many depositors lose their money. On the other hand, whether bank shareholders result benefited or not from the resolution depends on how policies are implemented and may vary across cases. In this respect, it is relevant to consider whether 
financial institution shareholders lose their capital in the resolution and whether they are penalized for excessive risk that they might have taken during the pre-crisis period. Furthermore, other issues such as related lending and looting, and the extent to which banks are punished for such practices, can be important to understand the outcomes for financial institution shareholders. As shown in the next section, the evidence suggests that banks do receive financial transfers during crises. ${ }^{15}$

\section{Who receives the financial transfers?}

Having studied transfers from individuals outside the financial sector to those inside the financial sector, we now further investigate who receives these transfers. Are all financial sector participants compensated for the losses arising from crises? If not, which are the participants that bear most of the losses? Do some participants even obtain capital gains from crises and their resolution?

Crises and policy measures can have uneven effects on different participants of the financial sector. A common example is the opposite impact that currency devaluations have on creditors and debtors. The devaluation of the currency, which typically accompanies crises, benefits holders of foreign currency deposits but affects adversely holders of foreign currency loans. ${ }^{16}$ This was the case in Chile, where foreign

\footnotetext{
${ }^{15}$ Besides the resolution tools described above, other mechanisms, which may be particular of each crisis, can contribute to transfers to the financial sector. For example, the resolution of the Argentine crisis caused important costs due to the "asymmetric stock pesification," i.e. the application of different conversion rates to bank loans and deposits (while dollar loans were switched at par, dollar deposits were converted at one dollar equal to 1.4 pesos). The cost of the additional 40 percent granted to depositors is estimated at 18.4 billion pesos (or near 6 billion dollars as of March 2003), and the cost of closing the open foreign exchange position that the asymmetric pesification left to banks at 9.8 billion dollars. The Argentine government decided to compensate banks for these costs.

${ }^{16}$ The impact of devaluation is especially important in Latin American countries as many of these economies have highly dollarized financial sectors.
} 
currency borrowers were severely hit by the devaluation of the peso. ${ }^{17,18}$ In this section, we explore this kind of asymmetric effects to identify who are the winners and who are the losers within the financial sector. As we are interested in studying the implications for income distribution, we focus on asymmetries between larger (and probably richer) participants and smaller participants of the financial sector. We find that large and foreign depositors result unharmed from crises and may even receive capital gains, while small depositors suffer capital losses. Also, among borrowers, we show that large and related companies often obtain large profits.

\subsection{Which depositors receive the transfers?}

We study capital gains and losses among depositors with evidence from the Argentine, Ecuadorian, and Uruguayan crises. As there are no data on the wealth of deposit holders, we use the size of deposits as a proxy. We assume, based on anecdotal evidence, that larger (or richer) depositors have deposits of larger size, while smaller (or poorer) depositors hold deposits of smaller size.

\section{Argentina}

We begin by analyzing the Argentine crisis. During 2001, Argentina faced a currency run that triggered a generalized bank run. ${ }^{19}$ As a result, Argentina suspended

\footnotetext{
${ }^{17}$ Authorities may take measures that reverse the effects of the currency devaluation. This happened in the Argentine crisis, where the conversion of dollar contracts into peso ones (pesification) hurt holders of dollar deposits and greatly benefited holders of dollar loans.

${ }^{18}$ Asymmetric impacts on creditors and debtors may also arise from other mechanisms or resolution tools. For example, in Ecuador, the government determined the interest rates to be applied to deposits and loans (of all banks) that were frozen in March 1999. As both deposit and lending interest rates were fixed at levels lower than market rates, this measure implied a transfer from depositors to borrowers (and financial institutions).

${ }^{19}$ See de la Torre, Levy Yeyati, and Schmukler (2003) and references therein for an analysis of the crisis.
} 
convertibility of their bank deposits on December 3, restricting cash withdrawals from bank accounts (by establishing the "corralito") and imposing extensive capital controls. This was followed by the devaluation of the peso on January 7 and a compulsory pesification and reprogramming of most bank deposits on February 3 ("corralón”). We find that the impact of these measures was not the same for all depositors.

An analysis of the evolution of deposits suggests some kind of information asymmetries that led to different behaviors and, thus, different effects on large and foreign depositors and small depositors. Figure 3 shows the cumulative change in private time deposits by currency, differentiating deposits held by foreign and local residents, and, in the case of local depositors, also discriminating by deposit size. We study changes in time deposits during two different periods: December 2000 - March 2001 and December 2000 - November 2001. (We cover until November because in December the authorities imposed the "corralito.") The two periods allow us to distinguish different behaviors at an early stage, when the future of the Argentine economy was still in doubt, and at a later time, when the scope of the crisis became evident.

For the period December 2000 - March 2001, the top panel of Figure 3 indicates visible differences between large and foreign depositors and small depositors. While small- and medium-size deposits (up to 100,000 pesos) increased over the period (by 21.7 and 10.1 percent in the case of peso and dollar deposits up to 5,000 pesos), large depositors and especially foreign depositors were already withdrawing their peso and dollar deposits (dollar deposits over 500,000 pesos fell by 14.3 percent and foreign dollar deposits by 22.3 percent). For the period December 2000 - November 2001, the bottom panel of the figure shows that withdrawals of peso deposits were generalized among 
depositors, though clearly more substantial in the case of large and foreign investors (peso deposits over 500,000 pesos and foreign peso deposits fell by 49.4 and 94.5 percent respectively, against a fall of 11.3 percent in peso deposits up to 5,000 pesos). Dollar deposits display a similar behavior, with the exception of deposits smaller than 5,000 pesos, which increased by 16.9 percent.

The evidence from Figure 3 suggests that large and foreign depositors, probably with access to timely and better information, ran before the government devalued the currency and pesified the deposits. ${ }^{20}$ They not only converted or withdrew their peso deposits, but also took their dollars out of the banking system. Small depositors, on the contrary, were at that time unaware of the vulnerabilities of the financial system. They realized about the risks of devaluation only a few months before it happened. The data suggest that holders of very small deposits (up to 5,000 pesos) did not expect, even in November 2001, the pesification of their dollar deposits. Also, besides a lack of information, small depositors probably faced much higher transaction costs to shift the money out. While large investors likely had foreign-based accounts, small depositors had no readily available investment options.

Local small depositors were the most hit by the crisis and pesification. They suffered the conversion of dollar deposits at one dollar equal to 1.4 pesos while the value

\footnotetext{
${ }^{20}$ The domestic-foreign division of losses and gains is a question of much debate. Regarding information asymmetries in particular, the literature focuses on capital markets and offers different views. On the one hand, Froot et al. (2001) and Seasholes (2000) suggest that foreign investors have better marginal information. On the other hand, Frankel and Schmukler (2000) show that local investors have informational advantages over foreign investors during times of crisis, and Brennan and Cao (1997) also indicate a "cumulative informational disadvantage" of foreign investors by looking at the correlation between inflows and returns. Note, however, that some of the foreign investors analyzed in this literature are small investors, while the foreign deposits considered in this paper are very large deposits. In this sense, the evidence that we show might not be comparable to the findings of the literature, as we are mainly analyzing the behavior of large (including foreign) versus small depositors, rather than domestic versus foreign investors.
} 
of the dollar in the market went rapidly over 1.7 pesos, reaching 3.86 pesos in June 2002. They were also the most affected by the imposition of the "corralito" and the forcible reprogramming of pesified time deposits. This can be shown by looking at the size of the deposit accounts that were reprogrammed. Figure 4 displays the distribution of reprogrammed time deposits according to the number of accounts as of July 2002, differentiating deposits that were originally denominated in pesos and dollars (by that time, all deposits had been converted to pesos). ${ }^{21}$ The figure shows that the "corralón" affected mainly small depositors, who were the ones that remained in the banking system. Time deposit accounts up to 5,000 pesos constituted 54 percent of total peso deposits and 48 percent of total dollar deposits that were compulsory reprogrammed. Large deposits, on the contrary, represented a small share of reprogrammed accounts.

Small depositors were also particularly affected because they did not receive the deposit insurance for which they were implicitly charged. Argentina had a partial deposit insurance scheme that was supposed to cover deposits up to 30,000 pesos or dollars, depending on their maturity. Since the deposit guarantee fund was constituted by mandatory contributions by financial institutions, banks transferred this cost to creditors by lowering the interest rate on small deposits. When the crisis and deposit drain began, however, deposit insurance funds were depleted. As there were no restrictions on the use of liquidity, banks responded to withdrawals by using all available funds. Liquidity was thus spent on returning deposits to those who ran first, namely large and foreign depositors. Small depositors, who had paid deposit insurance by earning less interest on their deposits, never saw their funds.

\footnotetext{
${ }^{21}$ Given the availability of data on reprogrammed deposits, we present the distribution by number of accounts and not by amount. Also, as we cannot distinguish between private and public or local and foreign deposits, we analyze the distribution of total time deposits.
} 
The results were very different for the large and foreign depositors who withdrew their deposits before December 2001. The evidence suggests that most of them took their money outside the country. As reported by the Argentine central bank, the accumulated private capital flight (excluding financial institutions) between December 2000 and December 2001 amounted to 12.9 billion dollars (or 5.1 percent of the 2001 GDP), which is comparable to the total deposit fall of 14.3 billion dollars during that period. ${ }^{22}$ This represented an increase of 13.6 percent in private external asset holdings, which reached 107.3 billion dollars in December 2001. ${ }^{23}$ The strong net foreign asset position of 72 billion dollars allowed large investors to hedge against capital losses arising from devaluation and pesification. Moreover, they benefited from changes in relative prices. While in December 2001 (before the devaluation) their net foreign asset holdings represented 28.6 percent of the current nominal GDP, by the first quarter of 2002 their net foreign asset position (equal to 75.8 billion dollars) could acquire 93.9 percent of the GDP. $^{24,25}$

\footnotetext{
${ }^{22}$ Additionally, some investors seem to have been able to move their money out even after the "corralito" was established. Indeed, the "corralito" allowed depositors to use their frozen deposits to purchase stocks listed on the Argentine exchange, thus providing a legal mechanism for transferring funds abroad via crosslisted securities. Auguste et al. (2002) and Melvin (2002) show that investors were able to purchase crosslisted stocks for pesos in Argentina, convert them into American Depositary Receipts (ADRs) or Certificados de Depositos Argentinos (CEDEARs), re-sell them in New York for dollars, and deposit the dollars in U.S. bank accounts. Given the costs of these transactions (ADR discounts were as high as 45 percent) as well as their high level of risk and complexity, only large investors are likely to have shifted their money out through cross-border trading. Note that this mechanism did not imply capital outflows for the overall economy, as explained by Levy Yeyati, Schmukler, and Van Horen (2003).

${ }^{23}$ Given the underreporting of external assets in Argentina, this figure is likely to be a very low estimative.

${ }^{24}$ For a similar analysis, see Mondino, Fernández Medrano, and Laspina (2002).

${ }^{25}$ In addition to the differential effects on small and large and foreign investors, the crisis resolution generated asymmetric results among the creditors whose deposits were reprogrammed. For example, some depositors who had their money in the "corralón" were able to get their dollars back through "amparos" (judicial injunctions).
} 


\section{Ecuador}

We can also study financial transfers to depositors with evidence from the Ecuadorian crisis. At the end of 1998, increasing depositor anxiety, external shocks, and a major systemic liquidity squeeze triggered a banking and currency crisis in Ecuador. ${ }^{26}$ Authorities had to abandon the exchange rate band on February 12 and establish a deposit freeze on March 15 (1999). A devaluation-insolvency spiral led finally to the adoption of dollarization, which was announced in January 2000. We show that these events impacted small and large depositors differently.

In the case of Ecuador, as there are no data on deposits by size, we study asymmetric effects on depositors by differentiating offshore dollar, onshore dollar, and onshore sucre deposits. ${ }^{27}$ Based on anecdotal evidence, we assume that offshore deposits belong to richer depositors, while onshore dollar and, particularly, onshore sucre deposits represent poorer depositors. Figure 5 shows the evolution of deposits by jurisdiction and currency between December 1998 and December 1999. (Note that only end-year data are available for offshore deposits during those times, what constrains our analysis. It would be ideal to be able to analyze the deposit run from August 1998 to March 1999, when the deposit freeze was imposed, though the Ecuadorian government gradually freed frozen deposits since April 1999.)

The top panel of Figure 5 shows that onshore sucre deposits in nominal terms increased by 25 percent in December 1998 - December 1999 (in terms of dollars, onshore sucre deposits fell due to the depreciation of the sucre). While onshore dollar

\footnotetext{
${ }^{26}$ See de la Torre, García-Saltos, and Mascaró (2002).

${ }^{27}$ Offshore banks in Ecuador were of a singular nature. These institutions had a license issued by a foreign, typically Caribbean country and were also authorized by the superintendency of banks to take dollar deposits from and grant dollar loans to Ecuadorian residents. By the mid-1990s, the offshore banking sector was about 70 percent the size of the onshore system. See de la Torre, García-Saltos, and Mascaró (2002).
} 
deposits fell by around 15 percent during this period, offshore deposits sharply decreased by more than 52 percent. The bottom panel of Figure 5 displays the change in the distribution of deposits as a result of the deposit run. Offshore deposits accounted for 40 percent of all deposits in December 1998 but for only 23 percent in December 1999. Moreover, the share of onshore sucre deposits, on the contrary, increased from 37 to 54 percent during that period.

The evolution of deposits depicted in Figure 5 confirms the different depositor reactions found in the Argentine crisis. While there was no run in the Ecuadorian onshore system, offshore large depositors withdrew most of their funds as the crisis approached. ${ }^{28}$ As a consequence, capital gains and losses resulted among different depositors. Small, onshore depositors, who did not withdraw their money, suffered the deposit freeze and dollarization of their funds. (The freeze was also applied to most of the deposits that remained in the offshore system.) The dollarization converted deposits at the new rate of 25,000 sucres per dollar, instead of applying the pre-freeze rate of around 10,090 sucres per dollar. Therefore, small depositors who had onshore sucre deposits frozen in the system bore a decrease in the value of their funds of more than 60 percent. In addition, many small, onshore depositors had their money in banks that were taken over by AGD. As mentioned above, the majority of these depositors had to wait months or years to recover their deposits, and many others have not received their funds yet. As of March 2003, AGD still had to return deposits to 3,246 individuals (a total of 103 million dollars). ${ }^{29}$

\footnotetext{
${ }^{28}$ Though they had deposits in the offshore system, this was not sufficient, as the crisis proved, to ensure that the resolution would not affect them.

${ }^{29}$ In addition to deposits of individuals, AGD owes 654 million dollars on account of foreign trade deposits, non-guaranteed deposits, and deposits in other institutions.
} 
The results for the large depositors who withdrew their money from offshore banks were of course very different. These large investors escaped from the deposit freeze, the dollarization, and the takeover of banks. The evidence suggests that withdrawals in the offshore system were financed by central bank liquidity. First, offshore banks lacked other liquidity sources to face the deposit run since external credit lines had dramatically dried up (falling from almost 2.5 billion dollars in August 1998 to near 1 billion dollars in December 1999). Second, as already mentioned, the Ecuadorian central bank was providing extensive liquidity assistance to onshore banks (2.3 billion dollars between August 1998 and December 1999), at the same time that onshore deposits were actually increasing. It is thus likely that onshore banks transferred central bank liquidity assistance to their offshore affiliates, allowing larger depositors to take their funds out of the system. This redirection of liquidity from onshore to offshore banks is reflected in the capital flight of near 730 million dollars between December 1998 and December 1999 (as reported by central bank of Ecuador), compared to a deposit fall of around 1.6 billion dollars in the offshore system during that period.

\section{Uruguay}

We also study the impact of the Uruguayan crisis on different depositors. The deposit run in Uruguay was mostly caused by contagion effects from the Argentine crisis. Deposit withdrawals started in December 2001 and January 2002 in the two largest private banks in Uruguay, Banco de Galicia Uruguay (BGU) and Banco Comercial, which were affiliated to Argentine banks. ${ }^{30}$ The deposit outflow spread through the rest

\footnotetext{
${ }^{30}$ Banco Comercial was not only affected by the Argentine crisis but also, and to an even greater extent, by the implication of a former board member and shareholder in alleged fraudulent activities involving the
} 
of the Uruguayan financial system in the second quarter of 2002, generating a fall in international reserves of more than 1.6 billion dollars by mid-2002. On June 19, the central bank had to abandon the crawling peg and allow the peso to float. Dollar time deposits of state-owned banks (Banco de la República Oriental del Uruguay and Banco Hipotecario del Uruguay) were reprogrammed to maturities of one and three years.

Figure 6 displays the evolution of deposits in December 2001 - December 2002 by size, currency, and residence. All private banks in the system are included with the exception of BGU and Banco Comercial, due to data availability. ${ }^{31}$ Though we miss a large part of the banking system, excluding BGU and Banco Comercial from the sample allows us to better analyze the response of depositors, apart from the withdrawals by those depositors who triggered the run.

Figure 6 shows that most of the deposit outflow from private banks was caused by large, foreign investors. Foreign depositors with dollar accounts over 25,000 dollars withdrew more than 2.7 billion dollars in December 2001 - December 2002, producing a fall in their deposits of 75.5 percent. Figure 6 also provides evidence of some differences among local depositors. While small depositors with accounts up to 25,000 dollars decreased their peso deposits by only 6.1 percent and their dollar deposits by 24.5 percent, larger investors reduced their peso and dollar deposits by 30.1 and 33.4 percent respectively. The bottom panel of the figure displays the consequent change in the composition of total deposits during 2002. The share of foreign dollar deposits over 25,000 dollars decreased from 52 percent in December 2001 to 27 percent in December

bank, its Argentine affiliate (Banco General de Negocios), and an Uruguayan affiliate (Compañía General de Negocios).

${ }^{31}$ There are no data by size for state-owned banks and there is no updated information for BGU after December 2001 and Banco Comercial after March 2002. 
2002. Small deposits in pesos and in dollars increased their shares by three and four percentage points.

It is interesting to compare the evidence from the Uruguayan crisis with that from the Argentine and Ecuadorian crises. On the one hand, depositors' responses in Uruguay appear to be in line with the conclusions drew from the experiences of Argentina and Ecuador. Figure 6 shows that large and particularly foreign investors, in contrast to small depositors, reacted more rapidly to the crisis by taking their money out of the system. On the other hand, in the case of Uruguay it is hard to assess whether information asymmetries, transaction costs, or other factors are behind these dissimilar behaviors. Most of the foreign, large depositors who withdrew their funds were Argentines, who were probably in need of liquidity due to restrictions imposed in their country. Another more important difference is that capital gains and losses resulting among depositors were much more limited in the Uruguayan crisis. Holders of peso deposits were hit by a currency devaluation of 84 percent between December 2001 and December 2002, and holders of dollar time deposits in state-owned banks suffered the reprogramming of their deposits. ${ }^{32}$ But the rest of the depositors did not suffer delays in the payment of their funds, and deposits were paid in most cases with the own bank resources. ${ }^{33}$ Moreover, depositors were not affected by deposit freezes or further changes in the value of their deposits due to pesification or dollarization measures, as happened in Argentina and Ecuador.

\footnotetext{
${ }^{32}$ Other depositors who suffered delays in the payment of their deposits were those with accounts in banks that were liquidated.

${ }^{33}$ The Uruguayan central bank provided liquidity assistance only to Banco Hipotecario, Banco Comercial, Banco La Caja Obrera, Banco de Crédito, and Banco Montevideo. In 2002, foreign bank shareholders made capital contributions for approximately 68 million dollars to Uruguayan private banks.
} 
The Uruguayan crisis provides a valuable example, though there are also some caveats to consider. An important lesson is that the effects of crises on depositors are not independent of resolution measures. While it might be difficult to mitigate the information asymmetries or differences in transaction costs to shift money abroad, the Uruguayan evidence shows that authorities can implement policies that reduce, or at least do not exacerbate, the negative impact on small depositors who remain in the system. Regarding the caveats, one could argue that the Uruguayan financial system is considerably smaller than the financial systems of Argentina and Ecuador. This can not only facilitate the resolution process for the authorities but also make it less costly for shareholders to make capital contributions and for international financial institutions to provide financial assistance. Another caveat to take into account is that the Uruguayan crisis occurred right after the Argentine crisis. Uruguay had probably learnt some lessons from the Argentine experience.

\subsection{Which borrowers receive the transfers?}

Evidence from several Latin American crises suggests that the effects of crises and their resolution are also uneven among borrowers. Though small debtors may not experience large capital losses (as small depositors do), capital gains are strongly concentrated in large companies with close ties with banks. We show that these related parties benefit from preferential loan conditions offered by their affiliated banks (transferring the cost of the unsound practices to the society), emerge relatively unharmed from the crises, and often end up profiting from public bailouts. We study the transfers 
received by large, related borrowers with data from the Chilean, Ecuadorian, and Mexican crises.

\section{Chile}

The Chilean banking crisis of 1981-1983 was originated in macroeconomic problems (caused by external and domestic factors) that substantially damaged the repayment capacity of bank borrowers. In June 1982, the government had to devalue the peso, weakening even more the capacity to pay of firms and banks. As explained by the literature, this situation was greatly aggravated by a surge of unsound financial practices resulting from a weak regulatory environment. ${ }^{34}$

Loose lending practices and particularly loan concentration in affiliated firms were important determinants of the Chilean crisis. Previous to the crisis, industrial and financial conglomerates acquired most of the country's largest manufacturing and banking firms. Immediately, the financial system was characterized by loan concentration in related businesses that were not creditworthy. In many cases, banks lent to firms controlled by their new owners so that these firms could use the proceeds to pay for the shares of these banks that they were buying. Also, many companies borrowed from their banks at preferential rates and bought stock among themselves, benefiting through price appreciation and then using the stocks as collateral for bank credit. The problem of the related portfolio in the Chilean banking system had become significant by June 1982: related loans accounted for 21.1 percent of the portfolio of the five largest private banks. Velasco (1988) concludes that Chilean banks would not have extended so many unsound loans if they had not gone to banks' own related firms, and that without

\footnotetext{
${ }^{34}$ See for example Larrain (1989) and Velasco (1988).
} 
that sizeable related portfolio, a financial crisis of Chile's proportions could have never occurred.

The extent of related lending contributed significantly to the large fiscal costs that this crisis generated. This suggests that the cost of the preferential treatment to related parties fell on the taxpayers (who pay the fiscal costs). Furthermore, related companies seem to have profited from the crisis resolution. We can show part of the transfer received by related firms by studying the amount of risky loans sold by financial institutions to the Chilean central bank under the program of acquisition of high risk portfolio (as mentioned before, the central bank recovered only a small fraction of this assistance). Figure 7 compares the percentage of loans sold to the central bank with the share of related loans over total loans for the largest banks of the system. ${ }^{35}$ The upward slope of the trendline in the graph suggests that the costly central bank assistance bore by taxpayers financed the advantageous and unsound loans granted to related parties. For example, the largest private bank of the Chilean financial sector, Banco de Santiago, sold 60.4 percent of its loans to the central bank and had 42.3 percent of its loan portfolio concentrated in related firms by December 1982.

\section{Ecuador}

Regarding the Ecuadorian crisis, much has been debated about the gains obtained by large, related firms. Various local newspapers and economic journals claim that related lending is one of the main causes of the large fiscal costs and redistributions that the Ecuadorian crisis generated. Though there are no formal statistics on the fraction of loans to related parties, it is widely known that the largest banks of the system belonged

\footnotetext{
${ }^{35}$ The banks in the figure are the ones for which these data are available.
} 
to financial and industrial conglomerates (owned in many cases by some of the richest families of Ecuador), whose businesses were financed through preferential bank credits. There is also evidence that the loan portfolio of Ecuadorian banks, especially of those finally taken over, was highly concentrated in a small number of large firms. As of June 2003, the average size of loans granted by banks under the control of AGD was 36,871 dollars, against an average size of 2,250 dollars for loans given by other private banks. Moreover, of the total portfolio of banks that were taken over, around 65 percent corresponded to 527 related clients with debts greater than one million dollars (Debate 2001). ${ }^{36}$ This portfolio, with a fraction of non-performing loans of 94 percent as of June 2003, was transferred to AGD despite the evidence of widespread related lending.

Anecdotal evidence suggests that related loans by Ecuadorian banks increased as the takeover date approached. Anticipating the government bailout, banks took advantage and granted large, cheap loans to their firms. An illustrative example is that of Filanbanco, one of the largest banks in Ecuador. ${ }^{37}$ Filanbanco's shareholders, the family Isaías, had reprogrammed loans to 36 companies owned by the family before losing control over the bank. These loans had special terms of two to seven years and subsidized interest rates, and were denominated in sucres (while the currency depreciation was already quite advanced in Ecuador). It was also found that 12 days before AGD took control of Filanbanco, the bank granted a loan of near 2.1 billion sucres with maturity of eight years and zero interest to one of the companies of the conglomerate. After that, Filanbanco not only transferred its liabilities and (non-

\footnotetext{
${ }^{36}$ Among these, there would be 120 borrowers who particularly refuse to pay their debts. See interview to the World Bank Assessor for the debt restructuring plan, Gerald Meyerman. Published as "120 large debtors do not pay" in the local newspaper El Comercio, March 13, 2001.

${ }^{37}$ See Debate (2001).
} 
recoverable) assets to AGD, but also received more than 500 million dollars from the government for recapitalization.

\section{Mexico}

Finally, another illustration of transfers to borrowers is provided by the Mexican crisis of 1994-1995. External shocks and political disturbance caused massive attacks against the peso and led to the devaluation of the currency on December 20, 1994. The crisis severely impacted the financial system, which was already fragile due to the lax regulation and supervision that had accompanied the rapid growth of credit in the previous years. The weak regulatory environment had permitted a high concentration of bank loans in related firms.

As in the cases of Chile and Ecuador, related lending seems to have greatly contributed to the Mexican crisis. La Porta, Lopez-de-Silanes, and Zamarripa (2003) show that 20 percent of total loans at the end of 1995 were to related firms. They find that related companies borrowed at lower interest rates and for longer maturities, were less likely to post collateral, offered fewer personal guarantees, and were more likely to default than unrelated ones. La Porta, Lopez-de-Silanes, and Zamarripa also compare related lending in banks that went bankrupt in the crisis and banks that survived. While the shares of loans to related parties for "bankrupt" and "survivor" banks were similar in 1993, the share for bankrupt banks significantly increased as the takeover approached. Since bankrupt banks then sold their non-performing portfolio to Fobaproa and received significant assistance from the government, the costs of these unsound lending practices seem to have fallen on taxpayers. 
While the evidence clearly shows that large borrowers with ties with banks benefit from preferential loan conditions, one may ask what happens to bank shareholders. Why do financial institutions grant unsound loans to related parties even though this can severely affect them and prevent them from continuing operating? The answer is very simple: because it is profitable. Bank shareholders provide cheap funds to their companies as long as their share of profits in their own companies is larger than the share of profits in the bank. As occurred in the Chilean, Ecuadorian, and Mexican crises, shareholders often lose control over their banks but not over their industrial assets. Therefore, banks have an incentive to go broke for profit at society's expense, that is, to loot. Akerlof and Romer (1993) explain that looting is particularly common when a government guarantees a firm's obligations, being the most obvious such guarantee the deposit insurance. In the three crises analyzed in this section, banks had an either implicit or explicit guarantee that the government would assume their liabilities. Banks thus took excessive risk and made loans to related parties at advantageous terms, expecting the authorities to bear the costs of such practices. In this sense, the financial transfer is not only received by large, related borrowers, but also by bank shareholders.

\section{Impact of financial transfers on inequality}

This section uses data from Mexico to study the implications of financial transfers for income distribution. ${ }^{38}$ We first estimate the income level of the different social groups involved in the transfer from individuals outside the financial sector to those

\footnotetext{
${ }^{38}$ Studying the impact of financial transfers on inequality for the five crises covered in the paper would be repetitive and add very little to the analysis.
} 
inside the financial sector. We then complete the analysis with evidence on capital gains and losses within the financial sector.

We begin by looking at the individuals receiving financial transfers, including financial institution shareholders, borrowers, and depositors. Bank shareholders and borrowers are likely to belong to the upper level of the income distribution. Shareholders are usually rich families, and borrowers are typically individuals with stable jobs and a certain level of current income that have access to the formal credit market. We thus focus on analyzing bank depositors. Figure 8 displays some data from a survey conducted in Mexico City in 2000. ${ }^{39}$ The top panel of the figure shows that financial services reach a very limited percentage of Mexico's urban population. Only 14 percent of the population has a savings/debit account, and a much smaller portion has access to checking accounts or time deposits. The large size of the "unbanked population" already suggests that the resolution costs of the crisis were directed to a privileged and small group of people.

We now analyze the income distribution of the "banked population," which is a small fraction of the total population. The bottom panel of Figure 8 shows the holdings of bank accounts by income level. More than half of the total accounts belong to the upper 20 percent of the income distribution. The bottom 50 percent of the income distribution, representing individuals earning less than 4,000 pesos per month (420 dollars) in 2000, has only 16 percent of the accounts in the financial system. These numbers suggest that fiscal costs are mostly benefiting high-income households.

\footnotetext{
${ }^{39}$ Due to data availability, we use 1998 and 2000 data in the analysis. This, however, may not affect our estimations, as this kind of data does not change significantly over time.
} 
The figures cited above are in fact largely overestimating the presence of poor families in the financial sector. First, the data correspond to a survey conducted in Mexico City, comprising only the urban population of the capital city of the country. Estimations for the whole country would undoubtedly indicate a smaller "banked population" (as a percentage of the total population) and a smaller share of bank accounts held by low-income households. Second, the distribution of deposits is reported by number of accounts (as there are no data available on the distribution of deposits by amount). If we considered the median value of the accounts held by each income group, then the portion of deposits that belongs to poor families would decrease significantly. ${ }^{40}$

Now we turn to the other side of the equation, the costs bearers. As fiscal costs are partly financed with taxation, we analyze the tax structure by income distribution. Figure 9 displays the value-added tax (VAT) incidence in Mexico by deciles per household income, calculated from the National Household Income and Expenditure Survey (ENIGH). The top panel shows some estimations of the shares of the total VAT paid by each decile. The five lower deciles pay 17.3 percent of total VAT revenues, which in turn implies that they would be paying 17.3 percent of the fiscal costs for the resolution of the banking crisis. Of course, upper income groups pay a greater portion of the taxes collected because they spend more on the levied items. However, if we study the burden of the VAT as a percentage of income, the VAT structure is not as progressive as it seems. The bottom panel of Figure 9 shows that the VAT paid as a percentage of the (average) income corresponding to each decile is very similar across deciles, with

\footnotetext{
${ }^{40}$ As a reference, data from the 1998 Survey of Consumer Finances (see Kennickell, Satrr-McCluer, and Surette 2000) indicate that the median value of transaction accounts held by families in the upper ten percent of the income distribution in the U.S. is more than 38 times the median value of the transaction accounts held by families in the bottom 25 percent of the distribution.
} 
averages of 4.3 and 4.5 percent for the lower and the upper five deciles respectively. Therefore, poor households would be bearing a significant cost should the authorities increase taxes to finance the resolution of the crisis.

The situation is not better when resolution costs are financed through lower spending or through inflation. As already mentioned, public spending cuts tend to affect mainly the poor as they rely more on social programs. There is evidence that marginal spending is progressive (expenditure expansions crowd-in poorer groups and thus improve the distribution of income) and that, conversely, contractionary policies or slower expansions are likely to be regressive. Similarly, a rise in inflation generates a larger impact on the poor, who typically hold a relatively greater proportion of their wealth in cash and whose income comes mostly from labor earnings.

These rough estimations for the Mexican crisis suggest that the transfer from individuals outside the financial sector to those inside the financial sector is also a transfer from poorer to richer families. Low-income households pay a share of the fiscal costs (which is sometimes even larger than that paid by high-income households) but may not be benefited at all by them, or may be benefited but in a much lower proportion or only through indirect channels, as the costs are directed towards rescuing the financial sector.

Capital gains and losses within the financial sector studied in the previous section also have important implications for the distribution of income. Small depositors, who appear to suffer capital losses due to devaluation, deposit freeze, pesification or dollarization at unfavorable rates, reprogramming of deposits, and other mechanisms, tend to be mostly low-income households. On the contrary, foreign and large investors, 
who obtain significant capital gains from the increased value of the funds that they take out of the financial system (and the country), tend to be individuals that belong to higher ranges of the income distribution. In addition, large borrowers with ties with banks, who benefit from advantageous loan terms and government bailouts, as well as the shareholders of the affiliated banks are undoubtedly in the top range of the income distribution. Therefore, the increase in income inequality caused through financial transfers is even larger when we consider who receives the transfers within the financial sector.

\section{Conclusions}

We have investigated the impact of crises on the distribution of income through a new cannel, namely financial transfers. By analyzing data from some of the most important Latin American crises during the last decades, we have shown that the fiscal cost of crisis resolution generally implies a transfer from non-participants to participants of the financial sector, including depositors, borrowers, and financial institutions. Furthermore, evidence on capital gains and losses within the financial sector indicates that only a few, privileged participants of the financial system receive these transfers. In particular large, foreign, and more informed depositors, as well as large and related borrowers, result greatly benefited, while small and less informed depositors bear significant losses. Our analysis suggests that financial transfers go from poorer to richer households and, thus, may increase inequality.

There are some caveats that should be discussed. First, this study only uses evidence from country cases and does not present econometric estimations. While the 
paper clearly highlights the importance of financial transfers as a major channel of redistribution during crises, more formal and cross-country analyses would be welcomed. One alternative avenue could be to study the effects on inequality by analyzing changes in indicators such as the Gini coefficient during crises. Some papers present this kind of evidence, and a few of them try to relate it to the channels of impact traditionally cited in the literature. It would be interesting to test the contribution of financial transfers to these changes in inequality. One problem, however, is how to measure financial transfers. Moreover, since the cost of the transfers is usually financed over time through taxes, lower spending, and inflation, it is difficult to detect the effect of this channel vis-à-vis the other channels. Other problems are related to the lack of data to obtain meaningful regressions. Still, this type of test might be a way to formalize the evidence presented in the paper.

Second, the paper only covers transfers that involve the banking sector, whereas financial crises can affect income distribution through transfers in other financial markets. For example, what is the impact on the participants of the stock market? And what happens to holders of government and corporate bonds? Are there asymmetric effects between foreign and local investors in the bond market? How are pension funds affected and what are the implications? Incorporating financial transfers in other financial markets could help assess the final impact on income inequality.

Third, regarding fiscal costs, we must weigh the costs of the resolution against its benefits for the economy. Some studies argue that resolution policies increase fiscal costs and do not seem to reduce the scale of output losses that follow crises. On the other hand, it is difficult to assess the consequences of not restructuring the financial system, 
since most countries have intervened in one way or the other. If the authorities decide not to recapitalize banks or assist borrowers, the financial system could completely collapse. Given the importance of credit for the functioning of the economy, it is hard and very risky for a government to refrain from adopting resolution measures. Because of this, our analysis does not lead to the conclusion that resolution costs should not be incurred. Instead, we argue that policy tools should be designed by taking into account the financial transfers and income redistributions that they imply.

Finally, our findings have important policy implications. Regarding the transfer from non-participants to participants of the financial sector, we can distinguish ex-ante and ex-post measures. As noted above, it is clear that the authorities might want to prevent the breakdown of the financial system. In this sense, different actions taken exante tend to be more efficient and less costly than any rescue package offered in the aftermath of a crisis. ${ }^{41}$ The government could encourage market discipline and improve regulation and supervision to strengthen the financial system. This includes, among other things, a sound contractual and regulatory environment, rigorous monitoring that fosters risk awareness, risk-based capital requirements, and counter-cyclical provisioning requirements. As shown by Laeven and Majnoni (2002), banks on average create too little provisions in good times and are then forced to increase them during cyclical downturns, thus magnifying losses. A good example of counter-cyclical provisioning requirements is the system established in end-1999 by the Bank of Spain. ${ }^{42}$ The Spanish regulation highlights the co-movement between the economic cycle and solvency risk

\footnotetext{
${ }^{41}$ Note, however, that it is often very hard for authorities to avoid taking ex-post measures. In the aftermath of crises, governments have incentives to take actions due to political economy factors and pressures from interest groups.

${ }^{42}$ Circular No. 9/1999 of December 17, 1999.
} 
and thus requires the set up of "statistical loan loss provisions," in addition to a general provision and specific provisions for loans classified as doubtful. In other words, provisions must be set aside to cover transactions that have not yet been specifically identified as doubtful assets, but in which experience shows that this risk may exist. These provisions are built up in good times and then shifted into specific provisions in bad times (without passing through the income statement) as the loan portfolio decays. ${ }^{43}$

If the crisis already precipitated, however, there are also some issues to take into account. It would be beneficial that the government restrained the fiscal costs of its intervention. The literature on banking crises emphasizes the importance of a prompt resolution to reduce adverse effects and limit the overall costs (see, for example, Sheng 1996, Dziobec and Pazarbasioglu 1997, De Luna-Martinez 2000, and Honohan and Klingebiel 2003). A rapid and strict resolution could prevent fragile institutions from "gambling for resurrection" and stop the flow of funds to loss-making borrowers. Of course, it would be advisable to grant liquidity support to financial institutions in need as long as they do not present solvency problems, provided that liquidity and solvency problems can be disentangled. Also, it may be convenient that guarantees for depositors and debtors are not generalized, and their conditions are determined ex-ante. Limiting the bailout is important not only because of the high resolution costs that are paid by the whole economy, but also because of signaling and moral hazard problems that unrestricted aid produce. Authorities may want to ensure that their intervention provides signals and incentives that help decrease the likelihood of a subsequent crisis.

\footnotetext{
${ }^{43}$ These requirements appear to be more feasible than the adoption of counter-cyclical fiscal policies, which are generally interfered by political economy factors. Conversely, in the case of the financial sector, counter-cyclical behavior can be introduced through regulation, and also encouraged as best practice by international standards.
} 
The financing of the (restricted) assistance to the financial sector is also a question that deserves attention. Clearly, the impact of the bailout on the distribution of income depends on how it is financed. Since rises in taxes, spending cuts, or inflation would generally result in a net loss for individuals outside the financial system (who mostly belong to low income levels), it would be beneficial that governments consider alternative financing schemes. For example, a one-time wealth tax could be among the least regressive measures. Also, though its implementation might be difficult, a tax on large capital gains, perhaps imposed some time in the future, could shift more of the burden to the financial system and its (high-income) participants.

Concerning capital gains and losses within the financial sector, we can also consider ex-ante and ex-post measures. During tranquil times, the government could focus on increasing transparency to minimize information asymmetry problems and improving the supervision of banks' portfolios to prevent excessive risk taking through related lending. Good accounting and information disclosure standards and strict reporting requirements would be at the center of these policies. Once the crisis is in place, the policy discussion is more related to how the authorities intervene in the financial sector. On the depositor side, freezing or restructuring measures could discriminate deposits by type and size (see de la Torre, Levy Yeyati and Schmukler 2003). A good example is provided by the Uruguayan crisis, where the authorities concentrated central bank reserves on fully backing demand deposits in troubled banks in order to preserve the functioning of the payment system, while time deposits of troubled (state-owned) banks were restructured by decree. This preference to demand deposits appears to be crucial; as happened in the Argentine crisis, the collapse of the payment 
system may increase the cost of the crisis considerably, affecting output and employment and, thus, particularly hurting the poor. Moreover, this policy could be complemented by similar measures aimed at protecting small depositors. Since large and foreign investors run first, (ex-ante) stop-loss clauses on the use of liquidity could be imposed so there is something left to share among small depositors. Also, the government could force the reprogramming of time deposits only for deposits larger than a certain threshold, giving some form of priority of claim over available liquidity to small deposits.

On the debtor side, ex-post measures could also discriminate among loans. It would be important to differentiate among borrowers who cannot honor their debts due to the crisis, borrowers who were not able to pay their obligations even in good times, and borrowers who do have the resources to pay their loans but take advantage of the bailout and refuse to pay. Also, as shown in this paper, related lending deserves particular attention. Authorities that implement loan-purchase programs or other debt relief tools may want to avoid diverting costly assistance to firms that profited from unsound, advantageous loans. In relation to this, affiliated banks that engage in looting behavior could be punished, or at least excluded from any public assistance.

While some policy tools to minimize financial transfers can be proposed, it must be noted that political economy factors also play an important role. The political structure and sectoral interests may significantly affect regulatory and resolution policies. In the Mexican crisis, for example, bank borrowers organized themselves and forced the government to reassign part of the fiscal resources to support debt restructuring (see De Luna-Martinez 2000). ${ }^{44}$ In the Argentine crisis, the legitimacy of the pesification and

\footnotetext{
${ }^{44}$ Debtors also impeded reforms to the bankruptcy law that would have made easier for banks to take possession of guarantees and for the government to rapidly sell the acquired impaired assets.
} 
thus the ultimate effects of the crisis were subject to the influence over policymaking of different powers, such as Congress, the governors, and the judiciary. ${ }^{45}$ Although the specific impact of political economy factors on policy measures and financial transfers is difficult to predict, the final consequences for the distribution of income are likely to be negative. The poor do not tend to form organized groups, and therefore lack a political voice. As a result, their demands are not attended and poor households end being the most hurt by the policy adopted, which mainly responds to the interests of the government and other influential sectors. ${ }^{46}$

Lastly, policy recommendations as those presented above should be evaluated in light of the political constraints and institutional framework in the country, as well as the causes and effects of the crisis. What works in one case does not necessarily work in others. But it is important that policy decisions take into account the role of financial transfers during crises. This paper has provided evidence of sizeable transfers to large and privileged participants of the financial sector that may increase income inequality. The debate on crisis prevention and resolution should consider these wealth redistributions and aim to attain a more equitable loss sharing.

\footnotetext{
${ }^{45}$ As part of a long dispute, the Supreme Court sponsored a resolution that would declare pesification unconstitutional and mandate the redollarization of most pesified bank liabilities, significantly changing the allocation of the costs of the crisis. The government responded with a failed attempt to impeach all of its judges.

${ }^{46}$ This is clearly reflected, for example, by the decisions taken over the financing of the costs of a crisis. As powerful interest groups put obstacles to certain tax raises or public expenditure cuts, spending cutbacks on social protection and other programs targeted at the poor are often relatively larger.
} 


\section{References}

Akerlof, George A., and Paul Romer, 1993, "Looting: The Economic Underworld of Bankruptcy for Profit," Brookings Papers on Economic Activity, 2, pp. 1-73.

Agencia de Garantía de Depósitos, 2003, "Reporte Gerencial,” May.

Agénor, Pierre-Richard, 2002, "Business Cycles, Economic Crises, and the Poor: Testing for Asymmetric Effects," Journal of Policy Reform, forthcoming.

Auguste, Sebastian, Kathryn Dominguez, Herman Kamil, and Linda Tesar, 2002, "CrossBorder Trading as a Mechanism for Capital Flight: ADRs, CEDEARs and the Argentine Crisis,” NBER Working Paper No. 9343, November.

Baldacci, Emanuele, Luiz de Melo, and Gabriela Inchauste, 2002, "Financial Crises, Poverty, and Income Distribution," International Monetary Fund Working Paper No. 02/04, January.

Bordo, Michael, Barry Eichengreen, Daniela Klingebiel, and Maria Soledad Martinez Peria, 2001, "Financial Crises: Lessons from the Last 120 Years," Economic Policy, 16:32, pp. 51-82.

Bourguignon, François, Anne-Sophie Robilliard, and Sherman Robinson, 2001, "Crisis and Income Distribution: A Micro-Macro Model for Indonesia," mimeo, June.

Brennan, Michael, and Henry Cao, 1997, "International Portfolio Investment Flows," Journal of Finance, 52, pp. 1851-80.

Burnside, Craig, Martin Eichenbaum, and Sergio Rebelo, 2001, "Prospective Deficits and the Asian Currency Crises," Journal of Political Economy, 109:6, pp. 1155-93.

Calvo, Guillermo, and Carmen Reinhart, 2000, "When Capital Inflows Come to a Sudden Stop: Consequences and Policy Options," in P. Kenen and A. Swoboda (Eds.) 
Key Issues in Reform of the International Monetary and Financial System, Washington DC: International Monetary Fund.

Caprio, Gerard, Daniela Klingebiel, Luc Laeven, and Guillermo Noguera, 2003, "Banking Crises Database," The World Bank.

Cardoso, Eliana, 1992, “Inflation and Poverty,” NBER Working Paper No. 4006, March.

Chang, Roberto, and Andrés Velasco, 2001, “A Model of Financial Crises in Emerging Markets," Quarterly Journal of Economics, 116, pp. 489-517.

Cunningham, Wendy, and William Maloney, 2000, "Measuring Vulnerability: Who Suffered in the 1995 Mexican Crisis?" mimeo, World Bank.

De la Torre, Augusto, Roberto García-Saltos, and Yira Mascaró, 2002, "Banking, Currency, and Debt Meltdown: Ecuador Crisis in the Late 1990s," World Bank, In process.

De la Torre, Augusto, Eduardo Levy Yeyati, and Sergio Schmukler, 2003, "Living and Dying with Hard Pegs: The Rise and Fall of Argentina's Currency Board," Economia, Spring, pp. 43-107.

De Luna-Martinez, Jose, 2000, "Management and Resolution of Banking Crises: Lessons from the Republic of Korea and Mexico," World Bank Discussion Paper No. 413, March.

Debate, 2001, Coyuntura Nacional, Issue 52.

Diwan, Ishac, 2001, "Debt as Sweat: Labor, Financial Crises, and the Globalization of Capital," mimeo, World Bank.

Diwan, Ishac, 2002, "The Labor Share During Financial Crises: New Results," mimeo, World Bank. 
Dziobec, Claudia, and Ceyla Pazarbasioglu, 1997, "Lessons from Systemic Bank Restructuring: A Survey of 24 Countries," International Monetary Fund Working Paper No. 97/161, December.

Easterly, William, and Stanley Fischer, 2001, "Inflation and the Poor," Journal of Money, Credit, and Banking, 33:2, pp. 160-78.

Eichengreen, Barry, and Michael Bordo, 2002, "Crises Now and Then: What Lessons from the Last Era of Financial Globalization?” NBER Working Paper No. 8716, January.

Eichengreen, Barry, and Andrew Rose, 2000, "Staying Afloat When the Wind Shifts: External Factors and Emerging-Market Banking Crises," in G. Calvo, R. Dornbusch and M. Obstfeld (Eds.), Money, Capital Mobility and Trade: Essays in Honor of Robert Mundell, Cambridge, Mass.: MIT Press, pp.171-206.

Esquivel, Gerardo, and Felipe Larraín, "Explaining Currency Crises," 1998, Harvard Institute for International Development Discussion Paper No. 666, November.

Ferreira, Francisco, Giovanna Prennushi, and Martin Ravallion, 1999, "Protecting the Poor from Macroeconomic Shocks: An Agenda for Action in a Crisis and Beyond," World Bank Working Paper No. 2160, August.

Frankel, Jeffrey, and Andrew Rose, 1996, "Currency Crashes in Emerging Markets: An Empirical Treatment," Journal of International Economics, 41:3-4, pp. 351-66.

Frankel, Jeffrey, and Sergio Schmukler, 2000, "Country Funds and Asymmetric Information," International Journal of Finance and Economics, 5:3, pp. 177-95. 
Friedman, Jed, and James Levinsohn, 2002, “The Distributional Impacts of Indonesia's Crisis on Household Welfare: A "Rapid Response" Methodology," World Bank Economic Review, 16:3, pp. 397-423.

Froot, Kenneth, Paul O'Connell, and Mark Seasholes, 2001, “The Portfolio Flows of International Investors," Journal of Financial Economics, 59:2, pp. 151-93.

Giugale, Marcelo M., Olivier Lafourcade, and Vinh H. Nguyen (Eds.), 2001, Mexico: A Comprehensive Development Agenda for the New Era, World Bank.

Goldfajn, Ilan, and Rodrigo Valdés, 1997, "The Twin Crises and the Role of Liquidity," International Monetary Fund Working Paper No.97/87, July.

Goldfajn, Ilan, and Rodrigo Valdés, 1998, “Are Currency Crises Predictable?," European Economic Review, 42, pp. 873-85.

Hoggarth, Glenn, Ricardo Reis, and Victoria Saporta, 2002, "Costs of Banking System Instability: Some Empirical Evidence," Journal of Banking and Finance, 26:5, pp. $825-55$.

Honohan, Patrick, and Daniela Klingebiel, 2003, "The Fiscal Cost Implications of an Accomodating Approach to Banking Crises," Journal of Banking and Finance, 27:8, pp. 1539-60.

Kaminsky, Graciela, 1998, "Banking and Currency Crises: The Early Warnings of Distress," International Finance Discussion Paper No. 629, Board of Governors of the Federal Reserve System, October.

Kaminsky, Graciela, and Carmen Reinhart, 1999, "The Twin Crises: The Causes of Banking and Balance-of-Payments Problems," American Economic Review, 89:3, pp. 473-500. 
Kennickell, Arthur, Martha Starr-McCluer, and Brian Surette, 2000, "Recent Changes in U.S. Family Finances: Results from the 1998 Survey of Consumer Finances,” Federal Reserve Bulletin, 86, pp. 1-29.

Kim, Woochan, and Shang-Jin Wei, 2002, "Foreign Portfolio Investors Before and During a Crisis," Journal of International Economics, 56:1, pp. 77-96.

Klingebiel, Daniela, 2000, "The Use of Asset Management Companies in the Resolution of Banking Crises. Cross-Country Experience," World Bank Policy Research Working Paper No. 2284, February.

La Porta, Rafael, Florencio Lopez-de-Silanes, and Guillermo Zamarripa, 2003, "Related Lenidng," Quarterly Journal of Economics, 118:1, pp. 231-68.

Laeven, Luc, and Giovanni Majnoni, 2002, "Loan Loss Provisioning and Economic Slowdowns: Too Much, Too Late?," World Bank Policy Research Working Paper No. 2749, January.

Larrain, Mauricio, 1989, "How the 1981-83 Chilean Banking Crisis Was Handled," World Bank Working Paper No. 300, December.

Levy Yeyati, Eduardo, Sergio Schmukler, and Neeltje Van Horen, 2003, "The Price of Inconvertible Deposits: The Stock Market Boom during the Argentine Crisis," Economic Letters, forthcoming.

Lokshin, Michael, and Martin Ravallion, 2000, "Welfare Impacts of the 1998 Financial Crisis in Russia and the Response of the Public Safety Net," Economics of Transition, 8:2, pp.269-95. 
Lopez-Acevedo, Gladys, and Angel Salinas, 2000, “How Mexico's Financial Crisis Affected Income Distribution,” World Bank Policy Research Working Paper No. 2406, July.

Lustig, Nora, 2000, "Crises and the Poor: Socially Responsible Macroeconomics," forthcoming in Economia.

Manuelyan Atinc, Tamar, and Michael Walton, 1998, "Social Consequences of the East Asian Financial Crisis,” mimeo, World Bank.

Martinez Peria, Maria Soledad, and Sergio Schmukler, 2001, "Do Depositors Punish Banks for 'Bad' Behavior? Market Discipline, Deposit Insurance, and Banking Crises," Journal of Finance, 56:3, pp. 1029-51.

Melvin, Michael, 2002, “A Stock Market Boom during a Financial Crisis? ADRs and Capital Outflows in Argentina," Economic Letters, forthcoming.

Milesi-Ferretti, Gian Maria, and Assaf Razin, 2000, "Current Account Reversals and Currency Crises: Empirical Regularities,” in P. Krugman (Ed.), Currency Crises, University of Chicago Press.

Mondino, Guillermo, Esteban Fernández Medrano, and Luciano Laspina, 2002, “Argentina’s Neopopulism Voyage,” LatinSource Monthly Report, December.

Sachs, Jeffrey, Aaron Tornell, and Andrés Velasco, 1996, "Financial Crises in Emerging Markets: The Lessons from 1995," Brookings Papers on Economic Activity, 1, pp. $147-215$.

Sahn, E. David, Paul Dorosh, and Stephen Younger, 1997, Structural Adjustment Reconsidered: Economic Policy and Poverty in Africa, Cambridge, United Kingdom; New York: Cambridge University Press. 
Sanhueza, Gonzalo, 2001, "Chilean Banking Crisis of the 1980s: Solutions and Estimation of the Costs," Central Bank of Chile Working Paper No. 104, August.

Seasholes, Mark, 2000, "Smart Foreign Traders in Emerging Markets," Working Paper, January.

Sheng, Andrew (Ed.), 1996, Bank Restructuring: Lessons From the 1980s, Washington, DC: The World Bank.

Standard and Poor's, 2000, Report on Ecuador.

Velasco, Andrés, 1988, "Liberalization, Crisis, Intervention: The Chilean Financial System, 1975-1985," International Monetary Fund Working Paper No. 66, July. 


\section{Figure 1}

\section{Fiscal Costs of Banking Crises}

\section{Percentage of GDP}

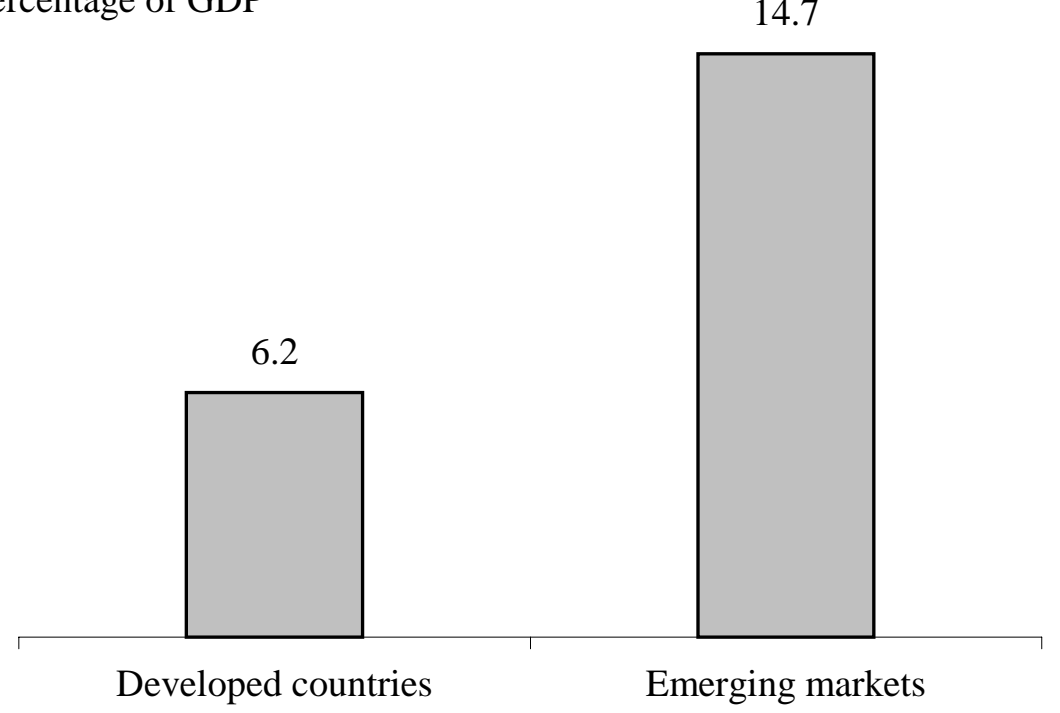

Number of crises

Average duration

Average depth
9

4.4

11.2
31

3.2

15.6

The figure shows the average fiscal costs of banking crises in developed countries and emerging markets. The sample includes a total of 40 crises. Average duration is the average recovery time in years. Average depth is the average cumulative output loss as a percentage of GDP.

Source: Honohan and Klingebiel (2003) 
Figure 2

Debtors Response to Takeover in Ecuador

Past-Due Loans Over Total Loans by Bank Type (in percent)

Private banks

AGD and state-owned banks

79.3

80.7
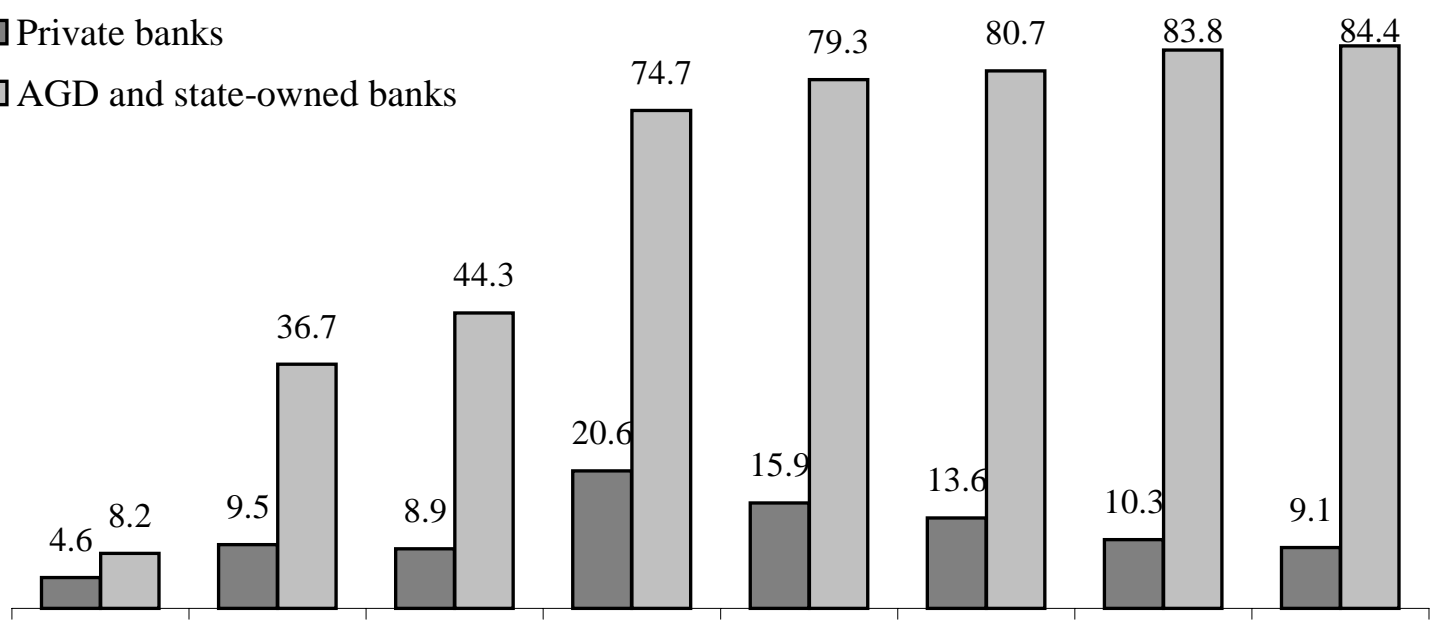

Dec 1998

Jun 1999

Dec 1999

\author{
74.7
}

44.3

36.7
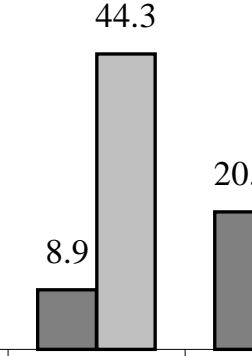

Participation of Private and AGD and State-Owned Banks in the System

\begin{tabular}{lcccccccc}
\hline & Dec 1998 & Jun 1999 & Dec 1999 & Jun 2000 & Dec 2000 & Jun 2001 & Dec 2001 & Jun 2002 \\
\hline Number of banks & & & & & & & & \\
Private banks & 37 & 33 & 26 & 26 & 24 & 21 & 21 & 21 \\
AGD and state-owned & 2 & 6 & 14 & 14 & 14 & 14 & 14 & 14 \\
$\begin{array}{l}\text { Percentage of system loans } \\
\text { Private banks }\end{array}$ & 82.0 & 74.7 & 42.0 & 43.4 & 40.3 & 47.5 & 53.1 & 69.1 \\
AGD and state-owned & 18.0 & 25.3 & 58.0 & 56.6 & 59.7 & 52.5 & 46.9 & 30.9 \\
\hline
\end{tabular}

\title{
Past-Due Loans Over Total Loans After Takeover (in percent)
}

$\square$ AGD and state-owned banks

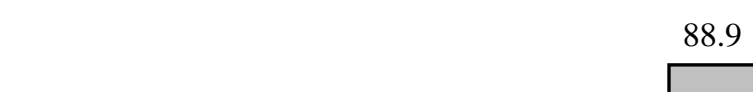

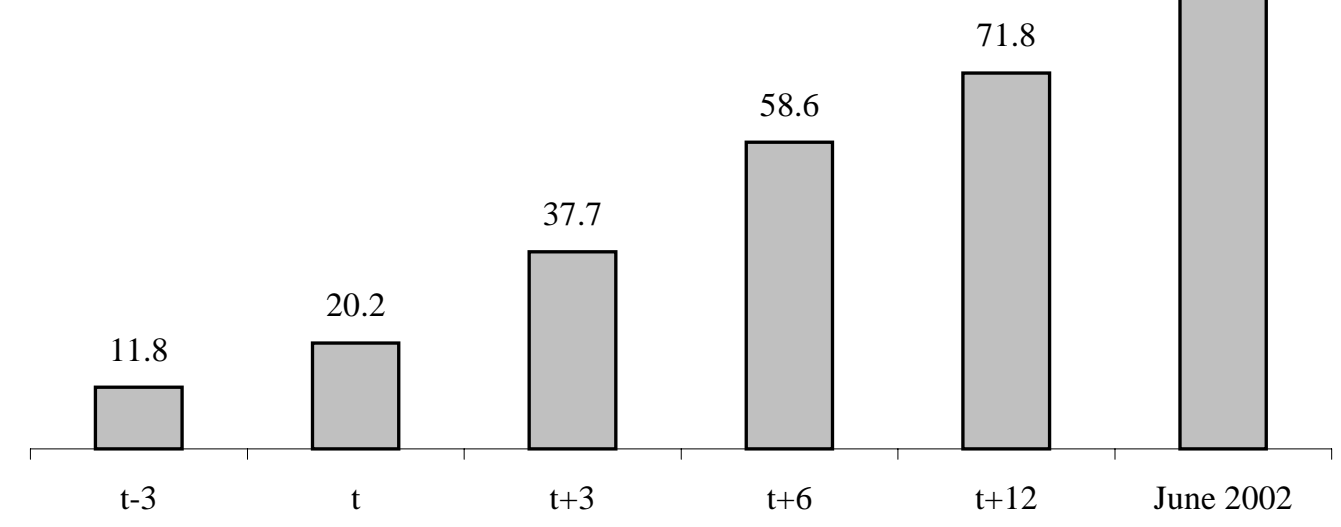

The top figure shows the evolution of the past-due loans share of private banks and banks taken over by AGD or the government, and the table shows the particpation of these banks in the system. The bottom figure shows how the past-due loans share changes for taken over banks relative to the takeover date (14 events are considered).

Source: Superintendency of Banks, Ecuador 
Figure 3

Cumulative Change in Time Deposits in Argentina (in percent)

December 2000 - March 2001

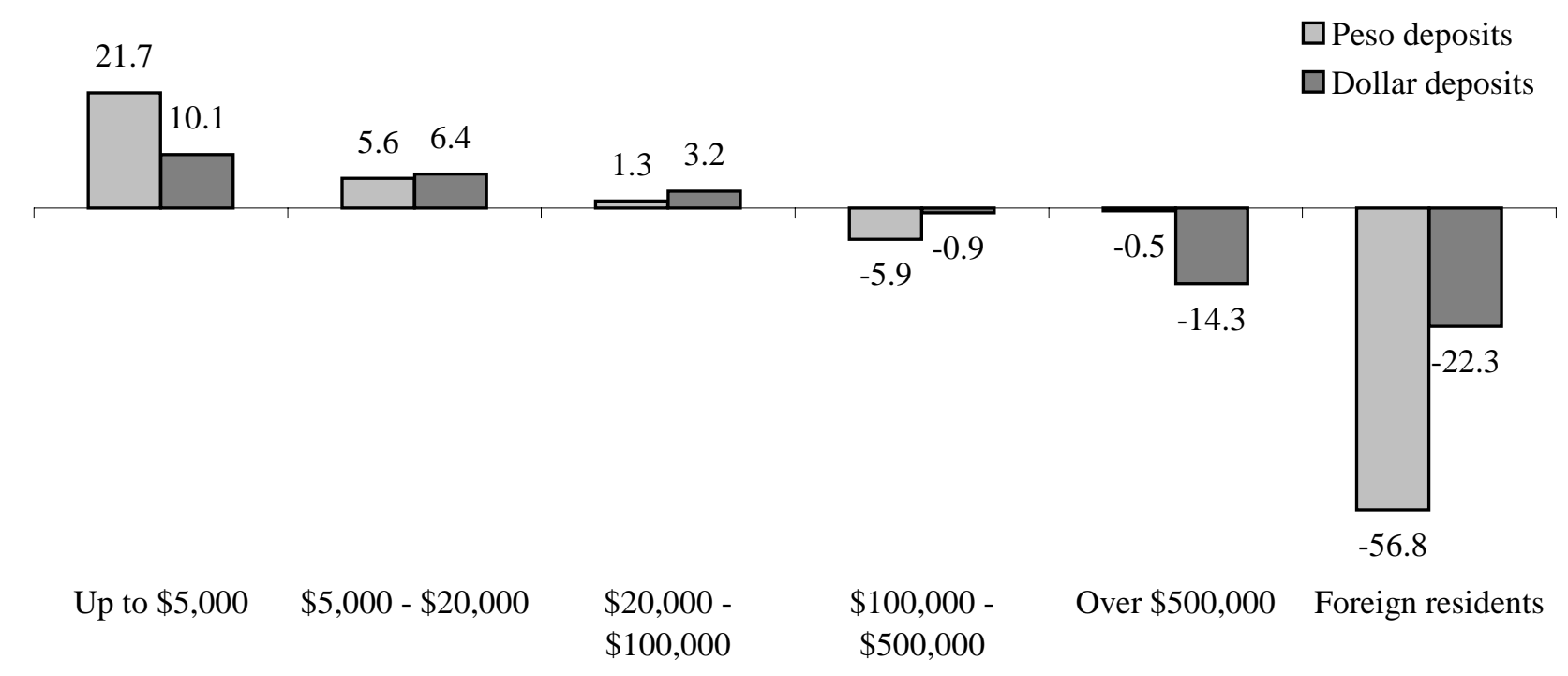

December 2000 - November 2001

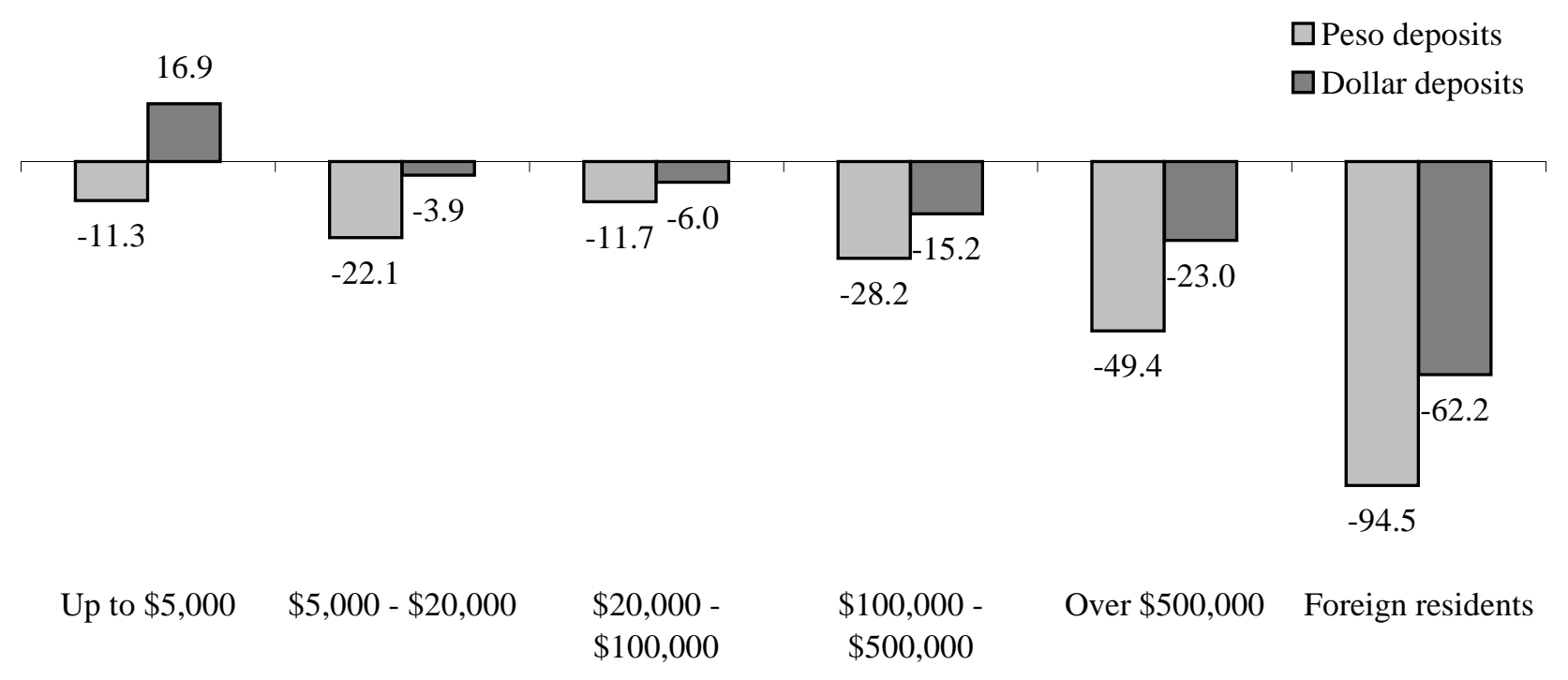

The figure shows the cumulative change in peso and dollar time deposits by residence and size of deposit for the periods December 2000-March 2001 and December 2000-November 2001. Note that the size of deposits is equally defined in terms of pesos or dollars as the Argentine exchange rate was still one peso per dollar.

Source: Central Bank of Argentina 
Figure 4

Distribution of Reprogrammed Deposit Accounts by Size in Argentina

\section{Peso Deposit Accounts}

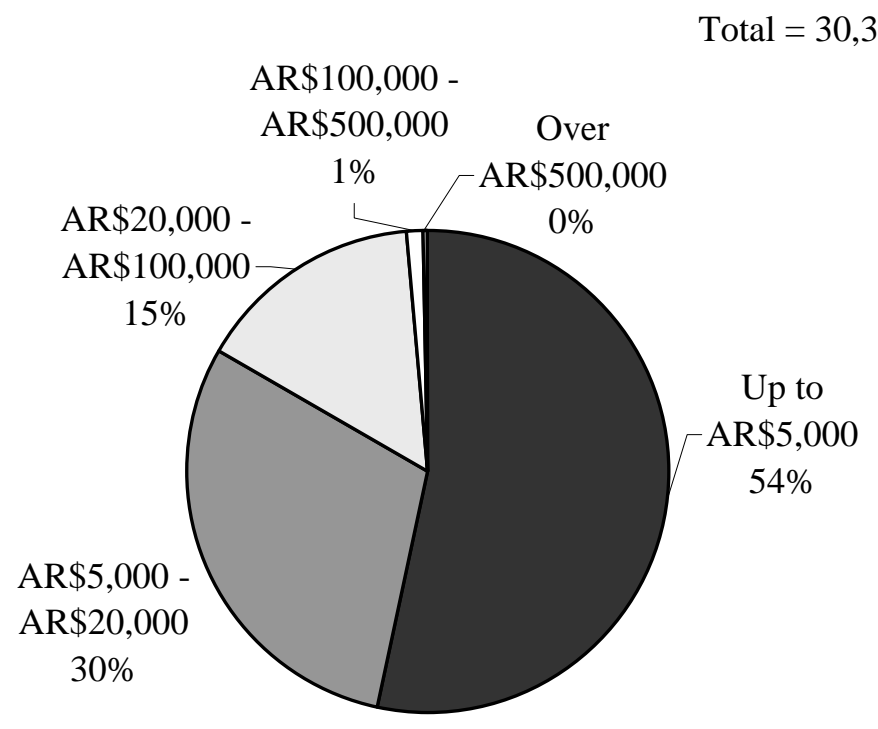

\section{Dollar Deposit Accounts}

Total $=934,061$ accounts

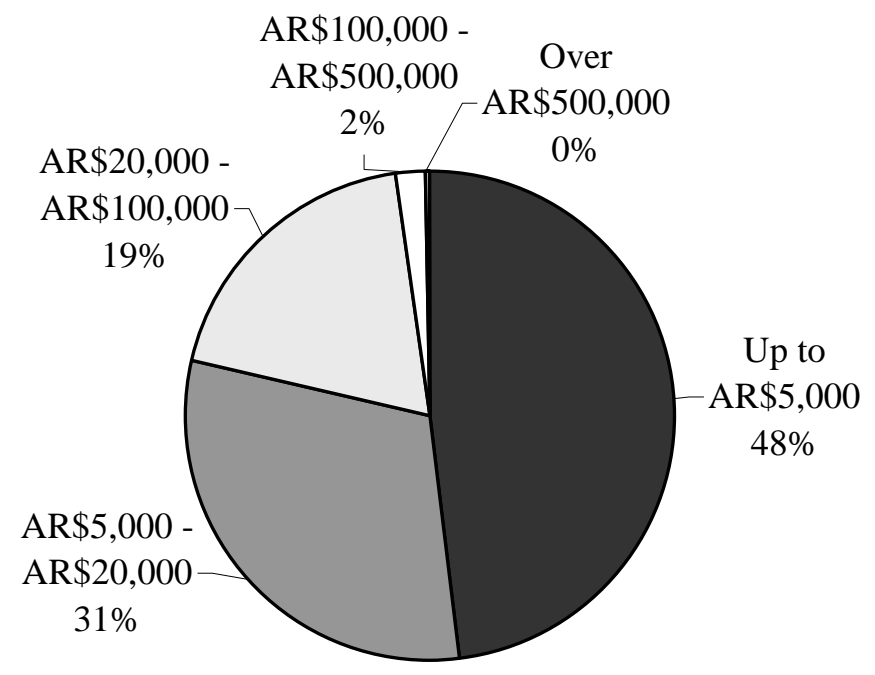

The figure displays the distribution of peso and dollar reprogrammed time deposits by deposit size according to the number of accounts as of July 2002. The size of deposits is defined in terms of pesos.

Source: Central Bank of Argentina 
Figure 5

Deposit Run in Ecuador

\section{Cumulative Change in Deposits in December 1998 - December 1999 (in percent)*}

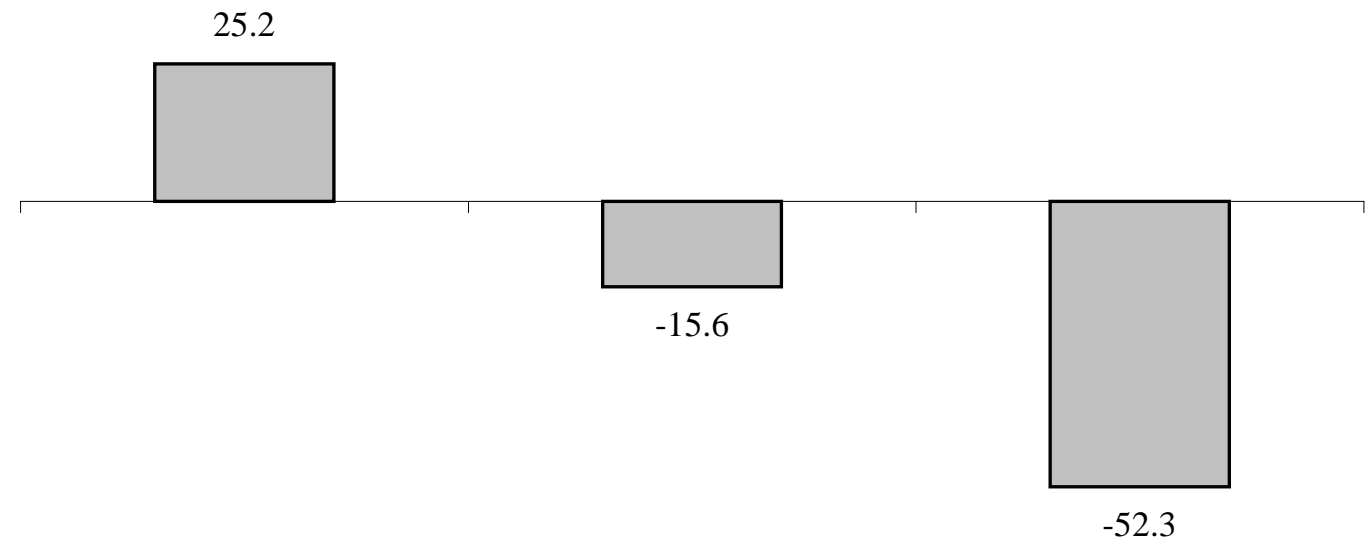

Onshore Sucre Deposits $\quad$ Onshore Dollar Deposits Offshore Deposits

\section{Distribution of Deposits by Currency and Jurisdiction*}

\section{December 1998}

Total $=\$ 7,485$ million
December 1999

Total $=\$ 6,335$ million

Onshore
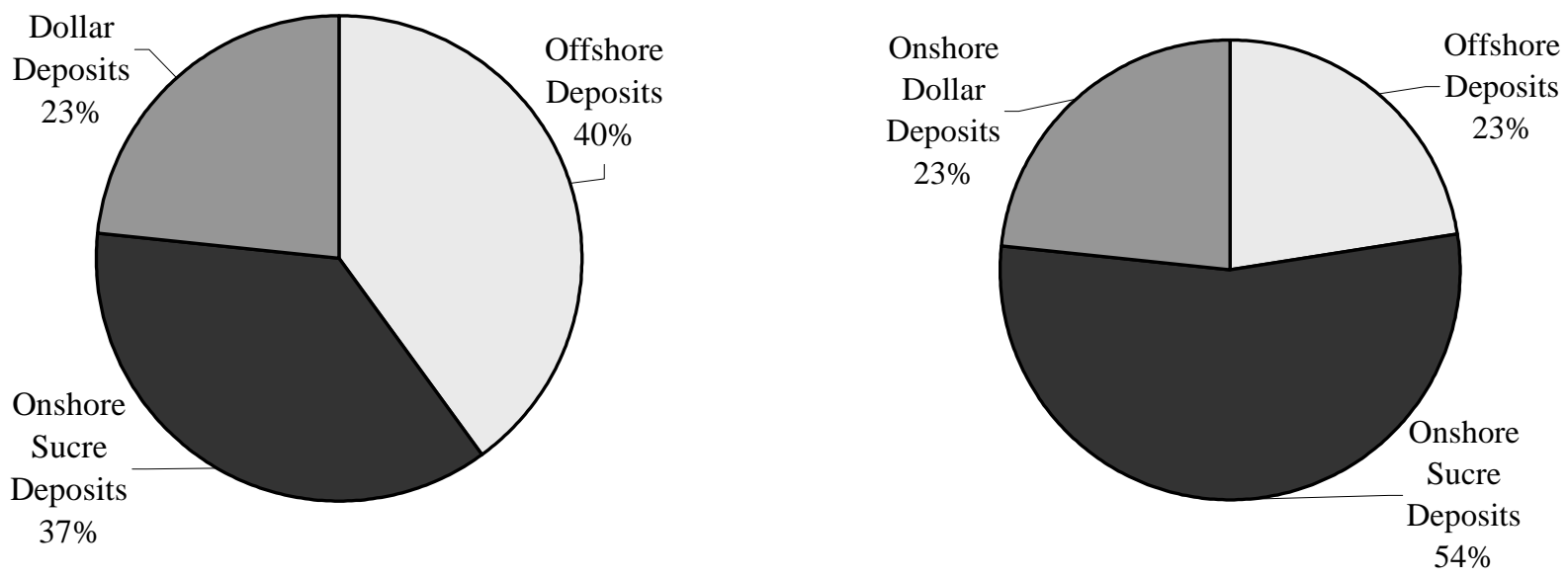

The top figure depicts the cumulative change in onshore sucre, onshore dollar, and offshore deposits for the period December 1998 . December 1999. The bottom figure shows the consequent change in the distribution of deposits during that period.

* Sucre deposits are in U.S. dollars as of December 1998 to show the nominal change.

Sources: Superintendency of Banks, Ecuador and Central Bank of Ecuador 
Figure 6

Deposit Run in Uruguay

\section{Cumulative Change in Deposits in December 2001 - December 2002 (in percent)*}

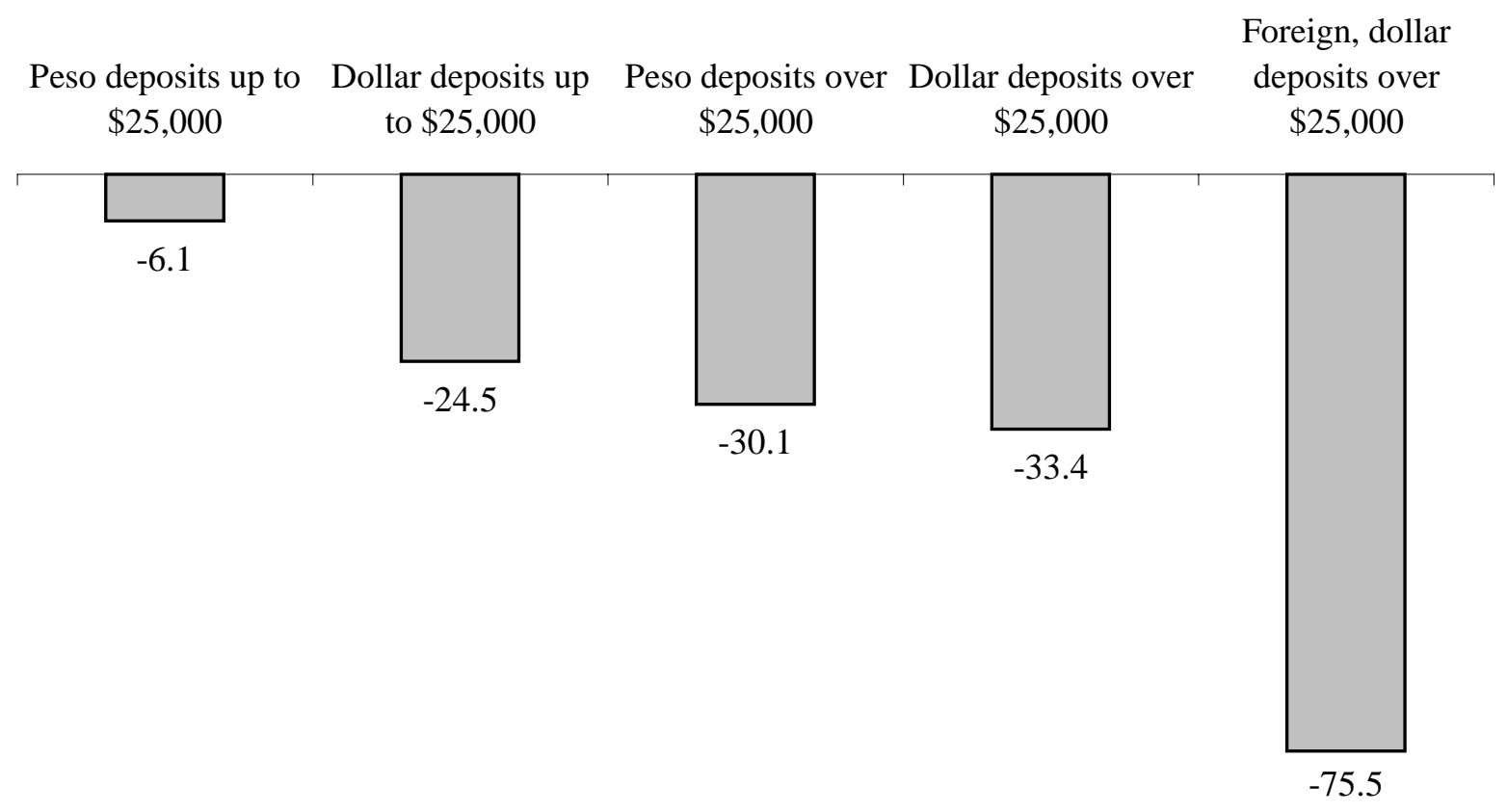

\section{Distribution of Deposits by Size, Currency, and Residence*}

\section{December 2001}

Peso up to Total $=\$ 7,736$ million

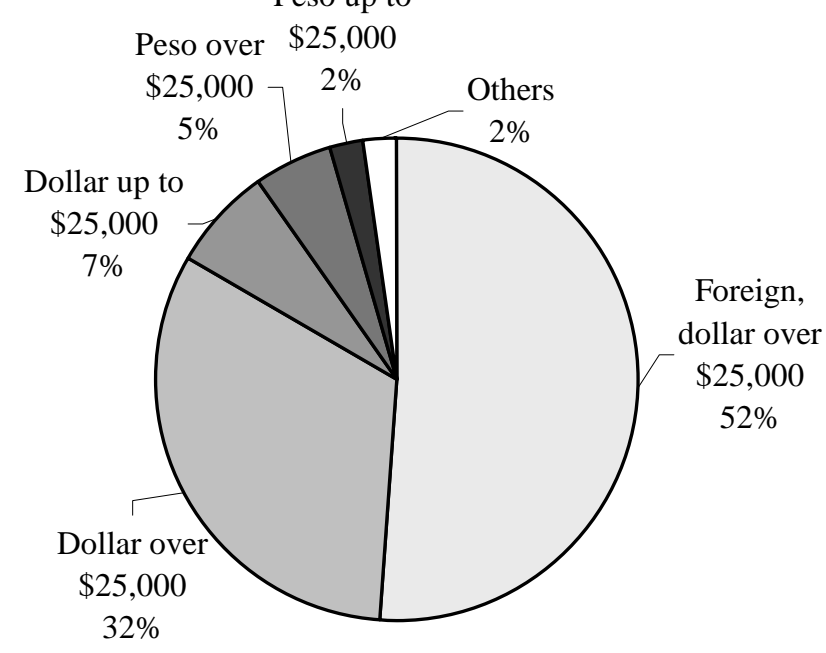

December 2002

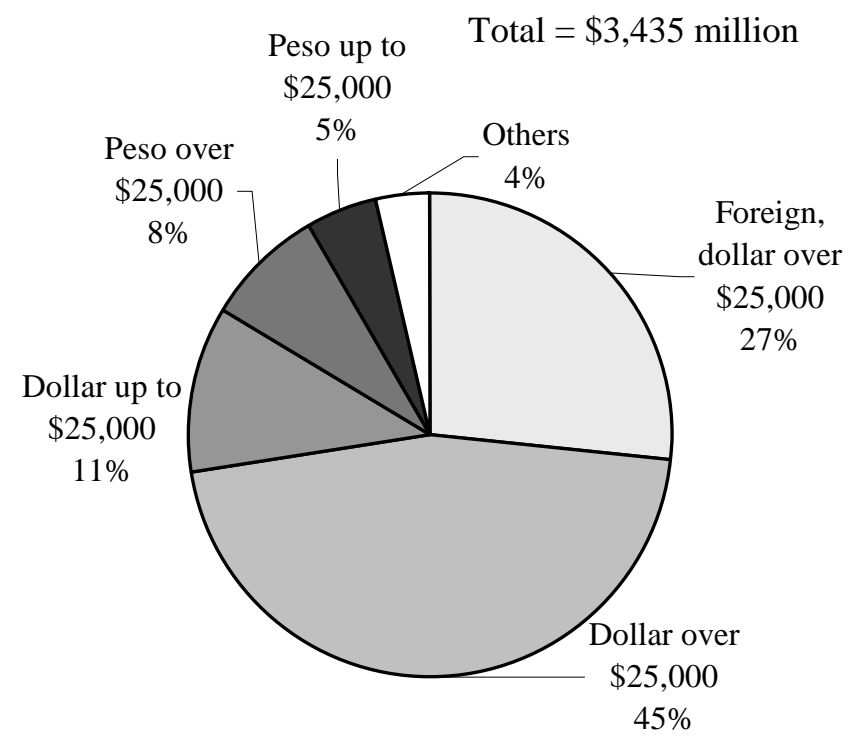

The top figure shows the cumulative change in peso and dollar deposits by deposit size and residence during December 2001December 2002. The bottom figure shows the consequent change in the distribution of deposits during that period. The size of deposits is defined in terms of dollars. All private banks with the exception of BGU and Banco Comercial are included. * Peso deposits are in U.S. dollars as of December 2001 to show the nominal change. Source: Central Bank of Uruguay 
Figure 7

\section{Related Lending and Central Bank Assistance in Chile}

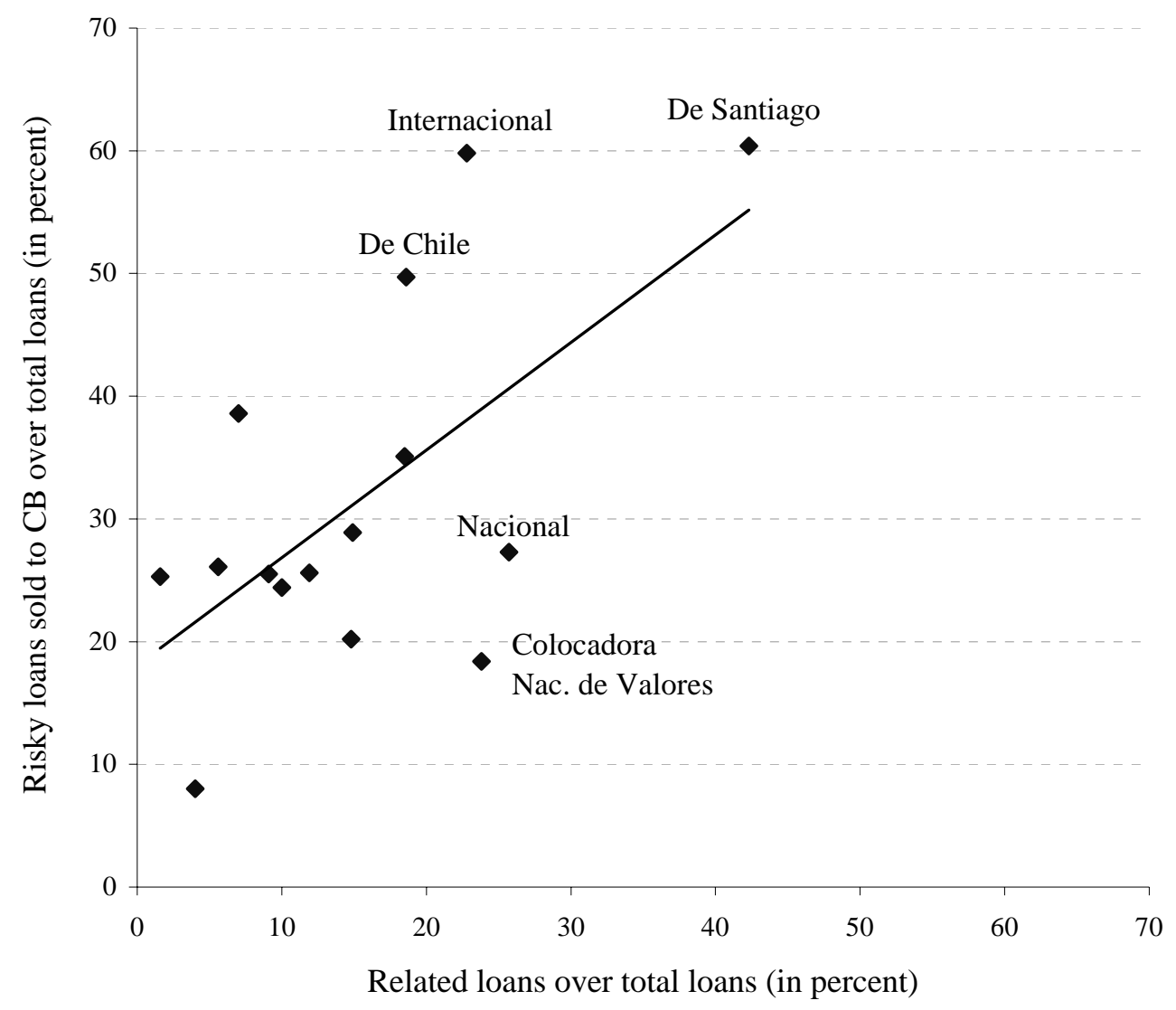

The figure displays the share of loans sold to the central bank relative to the share of related loans in the portfolio of the institutions.

Sources: Larrain (1988) and Sanhueza (2003) 


\section{Figure 8}

\section{Use of Banking Services in Mexico City (2000)}

\section{Percentage of Adults with Bank Accounts}

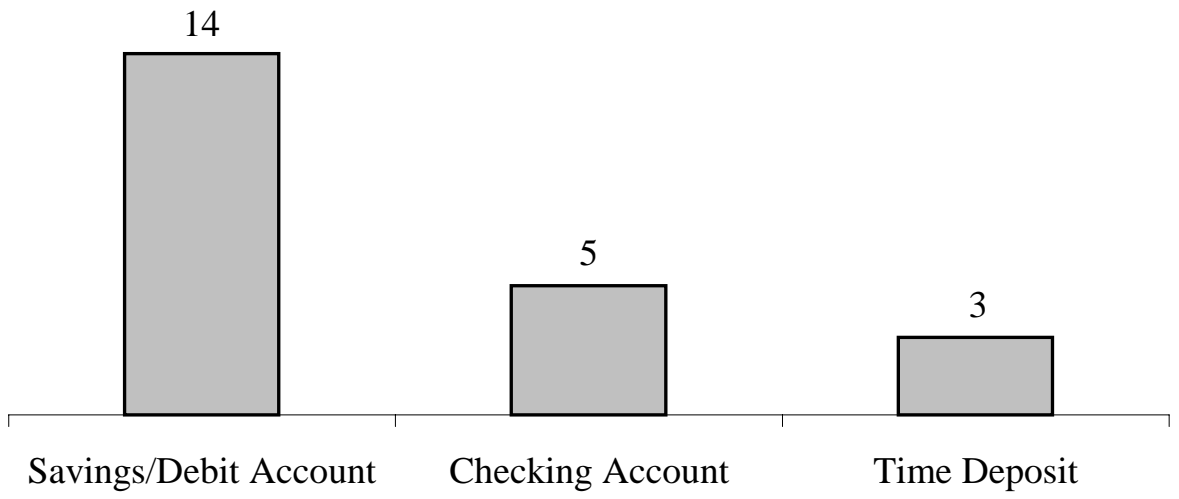

Holders of Bank Accounts by Income Level

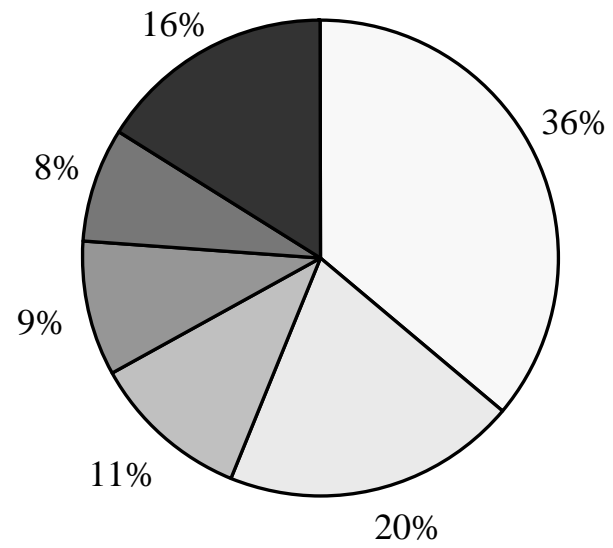

Income level

$\square$ Upper $10 \%$

$\square 80-99 \%$

$\square 70-89 \%$

$\square 60-79 \%$

$\square 50-69 \%$

Lower $50 \%$

The top figure shows the percentage of the population that has access to bank accounts. The bottom figure shows the distribution of bank accounts by income level according to the number of bank accounts held by each income group.

Source: BIMSA, General Media Study, 2000 for The World Bank 
Figure 9

Tax Incidence by Income Level in Mexico

\section{Percentage of Total VAT}

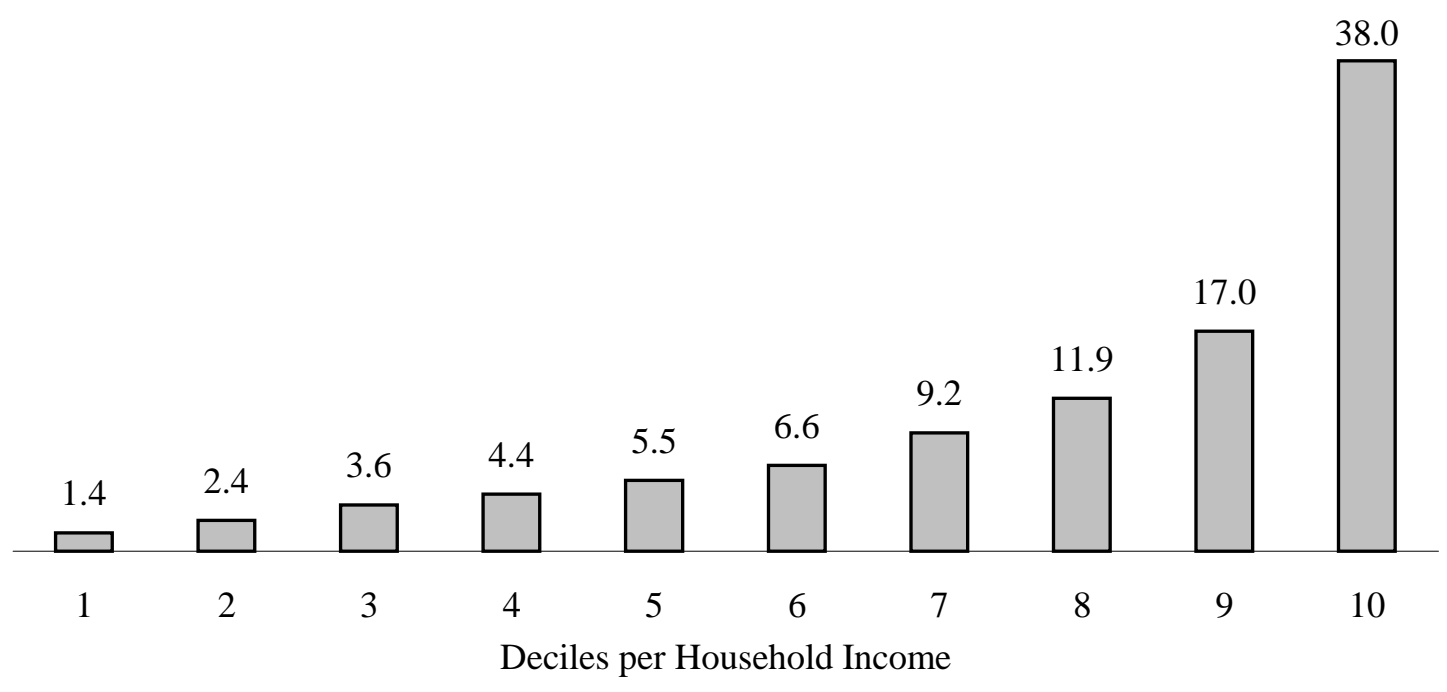

\section{VAT Burden as a Percentage of Income}

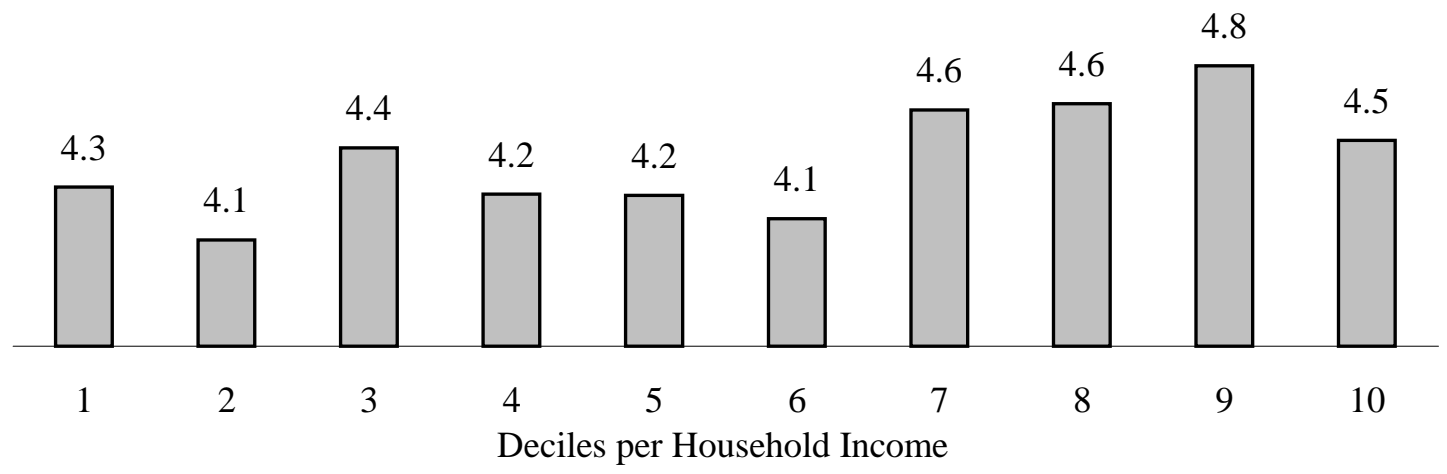

The top figure shows the percentage of total VAT paid by each household income decile. The bottom figure shows the VAT paid by each decile as a percentage of the average income corresponding to each decile.

Source: World Bank staff calculations based on the 1998 National Household Income and Expenditure Survey (ENIGH). See Giugale, Lafourcade, and Nguyen (2001). 